Derleme Makalesi- Review Article

\title{
Bitki Proteomik Çalışmalarında Kullanılan Yaklaşımlar ve Uygulama Yöntemleri
}

\author{
Aslihan GÜNEL ${ }^{1 *}$, Semra HASANÇEBİ ${ }^{2}$, Talat YALÇIN ${ }^{3}$, Mahmut EMİR ${ }^{4}$, \\ Yahya Emin DEMIRCII ${ }^{5}$, Melike DİNÇ ${ }^{6}$, Melda Zeynep GÜRAY ${ }^{7}$
}

Geliş / Received: 02/01/2020

Revize / Revised: 29/05/2020

Kabul / Accepted: 29/05/2020

\section{$\ddot{\mathbf{O Z Z}}$}

Proteomik yaklaşımları 2000 li yılların başlarına kadar mikroorganizmalar ve hayvansal kaynaklı örneklerde ağırlıklı olarak kullanıldı. Bu dönemde bitki proteomik çalışmaları yok denecek kadar azdır. Bitkisel dokulardaki sert hücre çeperleri, karmaşık ve çok çeşitli sekonder metabolitlerin varlığı, fazla miktardaki pigmentler, proteazlar, polifenoller, polisakkaritler, nişasta ve lipitler total protein örneklerinin hazırlanması ve proteinlerin ayrımı sırasında pek çok soruna neden olmuştur. Ancak her bir sorunun üstesinden gelmek üzere sürdürülen çabalar sayesinde bitki dünyasında da proteomik yaklaşım kullanımı yaygınlaşmıştır. Bu derlemede, örnek hazırlığından protein tanımlamaya kadar tüm basamaklar yöntemsel gelişmeleri de kapsayacak şekilde ayrıntılı olarak ele alınmış ve konuyla ilgili araştırıcıların maksimum yararlanabileceği bir kaynak oluşturulmaya çalışılmıştır.

Anahtar Kelimeler-Proteomik, Bitki proteomik, Kütle spektrometresi, 2D-PAGE, 2D-LC

\footnotetext{
1*Sorumlu yazar iletişim: agunel@ahievran.edu.tr (https://orcid.org/:0000-0001-5301-2628)

Ahievran Üniversitesi, Fen Edebiyat Fakültesi, Kimya Bölümü, Kırșehir

2illetişim: semrahasancebi@trakya.edu.tr (https://orcid.org/ 0000-0003-3898-7413)

Trakya Üniversitesi, Mühendislik Fakültesi, Genetik ve Biyomühendislik Bölümü, Edirne

3̇letişim: talatyalcin@iyte.edu.tr (https://orcid.org/0000-0003-3780-702X)

İzmir Yüksek Teknoloji Enstitüsü, Kimya Bölümü, Urla-İzmir

4İletişim: mhmtemr6@gmail.com (https://orcid.org/ 0000-0003-3834-811X)

Ahievran Üniversitesi, Fen Edebiyat Fakültesi, Kimya Bölümü, Kırşehir

İletişim: yemin 34@hotmail.com (https://orcid.org/ 0000-0003-4065-3498)

Yıldız Teknik Üniversitesi, Fen Edebiyat Fakültesi, Moleküler Biyoloji ve Genetik Bölümü, İstanbul

6İletişim: melikedinc@iyte.edu.tr (https://orcid.org/ 0000-0003-0466-1781)

İzmir Yüksek Teknoloji Enstitüsü, Kimya Bölümü, Urla-İzmir

7İletişim: mldguray@gmail.com (https://orcid.org/0000-0002-3092-7099)

İzmir Yüksek Teknoloji Enstitüsü, Kimya Bölümü, Urla-İzmir
} 


\title{
Approachs and Application Methods in Plant Proteomics Research
}

\begin{abstract}
Proteomics approach was used mainly in the samples for microorganisms and animal tissues until early 2000s, the period during which the plant proteomics studies were scarcely available. Tough nature of cell membranes, existence of complex and diverse range of secondary metabolites, high abundance of pigments, proteases, polyphenols, polysaccharides and lipids caused a number of problems for preparation and resolution of the protein samples. However, proteomics approach in plant area had become widespread with the help of continuous efforts in order to overcome these difficulties. This review is prepared comprehensively from the preparation of the samples to the identification of the proteins and it aims to serve as a detailed source for the researchers interested in plant proteomics, especially for young investigators.
\end{abstract}




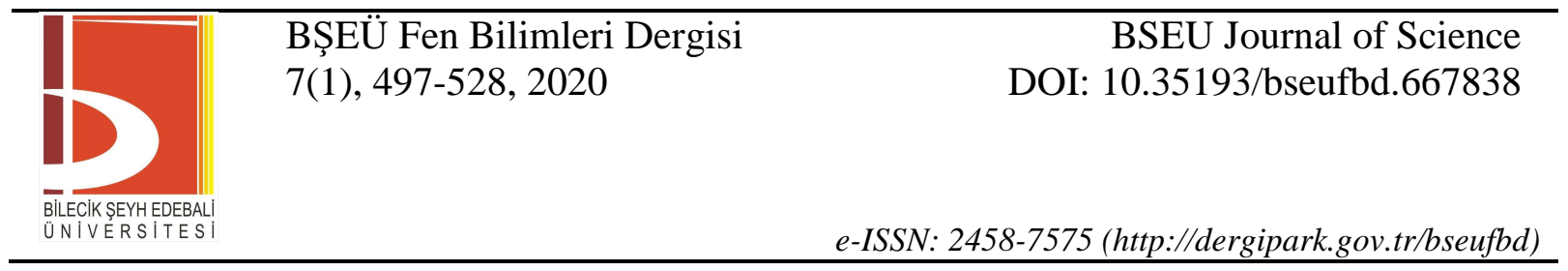

\section{GİRIŞ}

Son yıllarda genomik ve işlevsel genomik yöntemlerle birçok genin fonksiyonu tanımlanmasına rağmen tam olarak aydınlatılamayan biyolojik süreçler için araştırmacılar, bu süreçlerde doğrudan rol alan proteinler üzerine yoğunlaşmıştır. Bu gelişmeler genomik sonrası çağda proteomik, transkriptomik, metabolomik ve matematiksel modelleme sistemlerini de içeren sistem biyolojisi yaklaşımını doğurmuştur.

Genomik, işlevsel genomik ve transkriptomik yaklaşımlarla, belli bir biyolojik süreçle ilişkili farklı ekspresyon yapan birçok gen tanımlanmasına rağmen bunların fonksiyonel olup olmadığı halen açık değildir. Transkripsiyonel değişimler, çoğunlukla biyolojik süreçleri yöneten proteinleri veya protein seviyesindeki değişimleri tam olarak yansıtamamaktadır. Bunun önemli nedenlerinden biri, bir genin birden fazla protein kodlayabilmesi, mRNA ürününün transkripsiyon sonrası modifikasyonlarla, farklı biyolojik işlevlere sahip farklı proteinlere dönüşebilmesidir (Şekil.1). Bir diğer önemli neden ise post translasyonel modifikasyonlar ve proteinlerin kararlığındaki farklılıklardır. Çoğu durumda post translasyonel modifikasyonlar proteinin fonksiyonu ile doğrudan ilişkilidir. Dolayısıyla proteomik yaklaşımlar, bir biyolojik sürecin moleküler mekanizmasının aydınlatılmasında gerçeğe oldukça yakın sonuçlar ortaya koymaktadır.

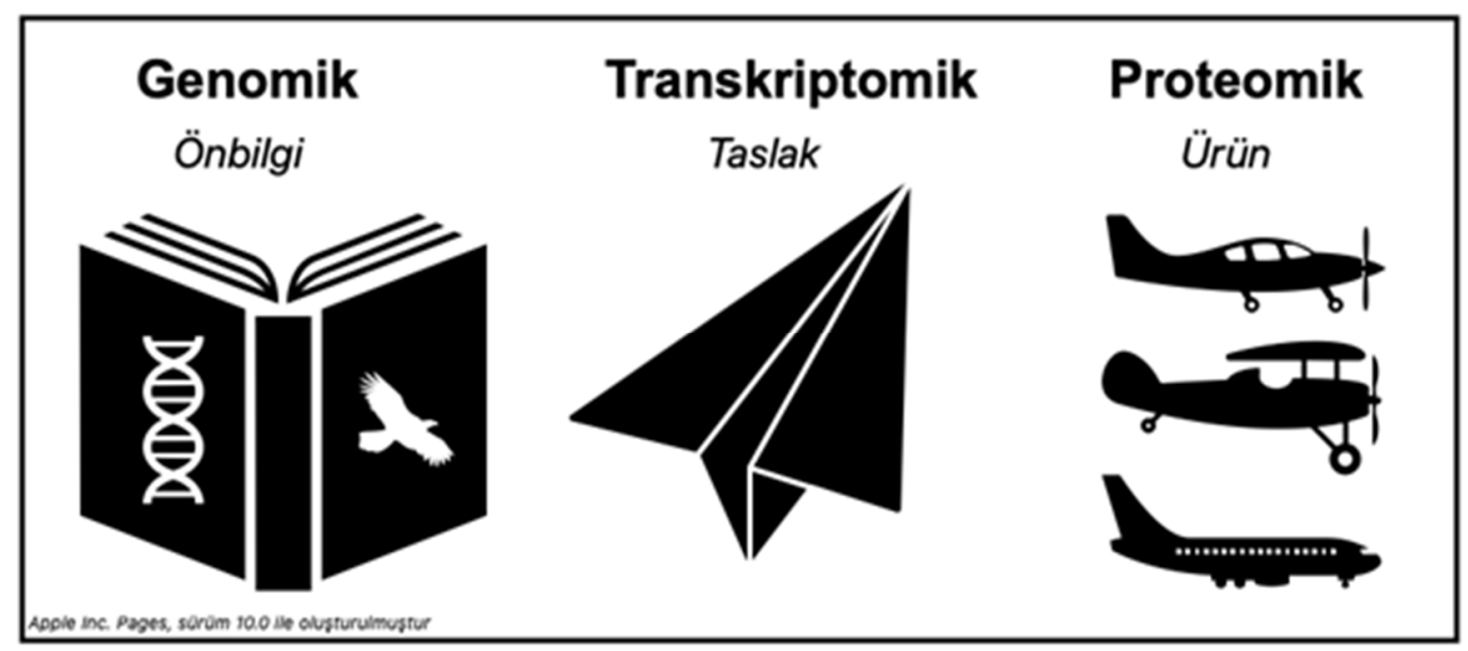

Şekil 1. Genom, transkriptom ve proteom arasındaki ilişkiye yönelik basit bir tasvir

Proteomik, proteinlerin yapılarını, fonksiyonlarını, birbirleri ile ve diğer moleküllerle etkileşimlerini geniş bir skalada inceleyen bir bilim dalıdır. Proteomik terimi, 1994'te Marc Wilkins'in "Proteom" terimini tanımlamasını takiben 1996 da literatürdeki yerini almıştır [1].

Proteomik çalışmalar, proteinlerin kompleks ve dinamik yapıları nedeniyle genomik çalışmalara oranla daha zordur ve ancak bir biyolojik sistemde belli bir koşul ve belli bir zaman dilimindeki mevcut proteinlerin analizine olanak tanımaktadır. Bununla birlikte canlının yaşamı boyunca karşılaştığı çeşitli durum ve streslere karşı geliştirmiş olduğu karmaşık metabolik ve düzenleyici reaksiyon yollarının detaylı biçimde incelenmesine olanak vermektedir.

Proteomik çalışmaların başladığı 1995 yılından bugüne kadar çeşitli kitap ve yayımlarda özel sayılar basılmaktadır. "Proteomics" dergisi spesifik olarak proteomik araştırmalarını kapsayan Wiley tarafından 2001 yılında basılmaya başlayan ilk bilimsel dergidir, ikinci sırada yer alan dergi ise American Society for Biochemistry and Molecular Biology tarafından 2002 yılında yayımlanmaya başlanan "Molecular \& Cellular Proteomics" tir. Bugün itibari ile proteomik alanındaki çalışmaların yayınlandığı 19 dergi bulunmakta ve sayıları artmaya devam etmektedir. Bununla birlikte kapsamlı ve müşterek yürütülen projelerde, proteomik sonuçları tamamlayıcı veya destekleyici katkılar sunmaktadır. 
Proteomik yaklaşımları 2000'li yılların başlarına kadar mikroorganizmalar ve hayvansal kaynaklı örneklerde ağırlıklı olarak kullanılmıştır. Bu dönemde bitki proteomik çalışmaları yok denecek kadar azdır. Bitkisel dokulardaki sert hücre çeperleri, karmaşık ve çok çeşitli sekonder metabolitlerin varlığı, fazla miktardaki pigmentler, proteazlar, polifenoller, polisakkaritler, nişasta ve lipidler total protein örneklerinin hazırlanması ve proteinlerin ayrımı sırasında pek çok soruna neden olmaktadır. Ancak her bir sorunun üstesinden gelmek üzere sürdürülen çabalar sayesinde bitki dünyasında da proteomik çalışmaların kullanımı yaygınlaşmıştır. Bugüne kadar 5610 (Google Scholar) "bitki proteomik" makalesi yayımlanmıştır. İlk bitki proteomik makaleleri 2001 yılında Konishi ve ark. ve Imin ve ark. tarafından Proteomics te basılmıştır [2,3]. Her iki çalışmada araştırmaya konu olan bitkisel materyal çeltiktir ki bu bitki ilk genom dizisi çıkarılan tahıldır. Konishi ve arkadaşları [2] tarafından gerçekleştirilmiş olan bu çalışma bitki patojen etkileşimi ile ilgili araştırmayı kapsamaktadır.

Bitkilerde proteomik çalışmalar, çeşitli bakış açılarını kapsamaktadır. Bunlar; a) yaprak proteomu [4] gibi bir organizmanın total proteom profillemesi, b) Arabidopsis kloroplast lümeni proteom haritalaması [5], pirinç yaprak kını proteom haritalaması [6], zorunlu biyotrofik mantarlar ve bitki arasında besin alış verişini sağlayan organ olan haustoria organelinin proteom haritalaması [7,8] gibi hücre altı proteom (subcellular proteomics) çalışmaları, c) tahıllarda pas hastalıklarına neden olan Puccinia triticina ile enfekte buğday yaprak proteomu [9], çeltikte yanıklık hastalığına neden olan Magnaporthe grisea ile enfekte çeltik proteomu [10] gibi biyotik ve abiyotik stresi temel alan çalışmalar [11], ve d) bitki patojenlerinin ekstraselüler proteinlerinin tanımlanmasını sağlayan sekretom analizleridir ki bu grup çalışmalara örnek olarak Verticillium albo-atrum ve Magnaporthe oryzae [4,12], sekretom analizleri ve Fusarium graminarium'un karşılaştırmalı sekretom analizleri [13] verilebilir.

Bitki proteomiğinin ilk yıllarında, model bitkiler de -özellikle Arabidopsis ve Çeltik gibi- gerçekleştirilen çalışmalarda genel olarak çeşitli bitki doku ve organlarının proteom profillemesi yapılmıştır. Bu çalışmalar dokulara özgü proteomik metotların geliştirilmesine de olanak sağlamıştır. Bir sonraki adım hücre altı proteomik çalışmalarıdır. Yöntemsel kısıtlar/zorluklar ve elde edilen protein miktarının düşüklüğü gibi nedenlerle bütün organizmalarda hücre altı proteomik çalışmalarının sayısı son derece azdır, bitkiler de ise oldukça kısıtlıdır. Bununla birlikte mısırda mitokondriyal proteomik [14], kloroplast proteomik [15,16], hücre duvarı çözünür proteinlerini kapsayan proteomik çalışması [17], Arabidopsis bitkisinde izotopla etiketlenme (ITRAQ) yöntemi kullanılarak endoplazmik retikulum, plazma membran, vakuol membranı ve golgi aparatlarının proteom profilinin çıkarılması [18], kastor yă̆ bitkisi (Ricinus communis) tohumlarının çimlenme ve gelişme dönemlerinde endoplazmik retikulum proteomlarının karşılaştırmalı incelendiği [19] çalışmalar bu alanda gerçekleştirilmiş önemli örneklerdir. Son yıllarda proteomiğin bitki dünyasındaki en yaygın uygulama sahası biyotik ve abiyotik stres toleransı ve moleküler mekanizmasıdır [20,21].

Özellikle biyotik stres toleransında son derece etkili olan bitkinin salg1 proteinleri (sekretom) son 10 y1lda oldukça ilgi duyulan bir alan olmuştur. Özellikle zorunlu biyotrof olan patojenlerin (külleme, pas hastalıklarına neden olan funguslar gibi) enfekte ettikleri bitki ile etkileşimlerinde sekretom profilleri bitki hücre duvarı ile plazma membranı arasında bulunan ekstraselüler sıvının izolasyonu, izole edilen sıvıdaki proteinlerin ekstraksiyonu ve proteomik tekniklerle tanımlanması ile gerçekleştirilmektedir. Çok yeni olan bu alanda yayınlanan araştırma sayısı oldukça azdır [21,22].

$\mathrm{Bu}$ yöntem bazlı derleme çalışmasında bitki proteomiğinin mevcut durumuna ilişkin çok kısa bir giriş verilmiştir, Derlemenin asıl amacı bu alanda çalışmak isteyen meslektaşlarımıza ve kariyerine yeni başlamakta olan genç arkadaşlarımıza, konu ile ilgili kullanılan teknikleri ve araçları, örnek hazırlığından itibaren detaylı şekilde vermektir. Dolayısıyla okuyucular yöntem odaklı bir akış ile karşılaşacaklardır.

\section{II: BITTKILERD KULLANILAN PROTEOMIKK METOTLARI}

Proteomik çalışmalarında temel olarak jel bazlı ve jelsiz proteomik yaklaşımları olmak üzere iki yaklaşım kullanılmaktadır. Jel bazlı yaklaşımlarda, iki boyutlu jel elektroforezi (2D-PAGE, two dimensional polyacrylamide gel electrophoresis) ile kombine edilmiş olan kütle spektrometresi (MS) analizlerini ve tek bir 2 boyutlu jel elektroforezi ile belli bir koşula tabii tutulmuş (ilaç uygulaması, hastalık, kuraklık, tuz vb.) olan test örneğinin kontrol örneği ile aynı jelde 2D-PAGE yöntemi kullanılarak ayrılmasını sağlayan DIGE (Differential gel electrophoresis)[23] ile kombine MS analizlerini içermektedir. DIGE tekniğinde kontrol ve test örnekleri farklı floresan özellikteki Cyanin boyalarla (Cy2, Cy3, Cy5 gibi) etiketlendikten sonra her iki örnek karıştırılır ve klasik 
2D-PAGE de olduğu gibi sonraki işlemlere devam edilir. Bir diğer teknik ise tek boyutlu jel elektroforezi ile ayrımın sağlanıp sıvı kromatografisi ile kombine edilmiş MS (LC-MS/MS) analizlerinin uygulandığı 1D-gel/LCMS/MS yaklaşımıdır.

İki boyutlu jel elektroforezini temel alan proteomik yaklaşımında bitki organ ve organellerinden amaca uygun bir metot ile ekstrakte edilen protein örneği 1.boyutta proteinlerin yüküne göre 2.boyutta ise yüklerine göre ayrılan proteinlerin molekül ağırlıklarına göre ayrılmasını temel almaktadır. Burada ayrıntılı bir şekilde bahsedeceğimiz 2 boyutlu jel elektroforezi yöntemi denatüre edici ve indirgeyici koşullarda gerçekleştirilmektedir. Ayrıca proteinlerin 3 boyutlu yapılarını koruyarak gerçekleştirilen 2D-PAGE yöntemi de özellikle membran proteinlerinin veya organel bazında gerçekleştirilen bitki proteomik çalışmalarında uygulanmaktadır. Bu amaçla kullanılan iki boyutlu elektroforez yönteminin adı ise 2D-BNPAGE (Two Dimensional blue native poliacrylamide gel electrophoresis) [24] dir.

\section{A. Jel Bazlı Yaklaşımlar}

Birçok biyolojik molekül gibi proteinlerin ayrımında da elektroforez yöntemi yaygın biçimde kullanılmaktadır. Elektroforezin çalışma ilkesi; elektrik alan uygulanmış bir jelde elektrik enerjisinin bir yükten diğerine giderken moleküllerin hareketini sağlaması ve moleküllerin molekül ağırlık ve boyut etkisi ile jelde kat ettikleri molekül ağırlığı ve molekülde bulunan elektrik enerjisinin jel içinden bir yükten diğerine giderken kat ettiği mesafe farklılıklarına dayanmaktadır [25]. Elektroforezde kat edilen mesafe, net yük ile doğru, molekül büyüklüğü ve ortamın viskozitesi ile ters orantılıdır. Elektroforezde destek ortam olarak agaroz ve nişasta jelleri kullanılmakla birlikte genellikle daha yüksek çözünürlükte ayrım için Poli Akrilamit jel (PAGE) tercih edilmektedir.

Proteinlerin ayrılmasında kullanılan sodyum dodesil sülfat poliakrilamid jel elektrofezi (SDS-PAGE) tekniğinde denatüre edici ve indirgeyici maddeler bulunmaktadır. Bu maddeler sayesinde proteinlerin alt birimleri birbirinden ayrılarak incelenir. Proteinlerin tek boyutlu ayrımında kullanılan SDS-PAGE de belli bir proteinin saflığı ve yapısı incelenirken bir yandan da az sayıda proteinden oluşan karışımların ayrılması sağlanmaktadır. Ancak proteomik çalışmalarda bir hücreyi oluşturan tüm proteinlerden oluşan bir karışım söz konusu olduğundan ayrım gücü daha yüksek yöntemlere gereksinim duyulmaktadır.

SDS-PAGE yöntemi ile izoelektrik odaklamanın (IEF) bileşimi olan 2D PAGE, kompleks protein karışımlarının ayrımında kullanılan önemli bir tekniktir. Bu yöntem ilk olarak 1975 yılında O' Farrel (1975) tarafından tanımlanmıştır ve moleküller birinci boyutta izoelektrik noktalarına (pI) göre ikinci boyutta ise molekül ağırlıklarına göre ayrılmaktadırlar. Klasik elektroforezden farklı olarak IEF (Şekil 2), proteinlerin bir pH gradyentinde $\mathrm{pI}$ değerlerine göre ayrılması prensibine dayanır. $\mathrm{Bu}$ yöntemde; $\mathrm{pH}$ gradyenti, düşük molekül ağırlıklı amfoterik maddelerin (amfolitler) yardımıyla oluşturulur. Bu moleküller, proteinler gibi bir pI değerine sahip oldukları için uygun pH noktalarında net elektrik yükleri sıfırdır.

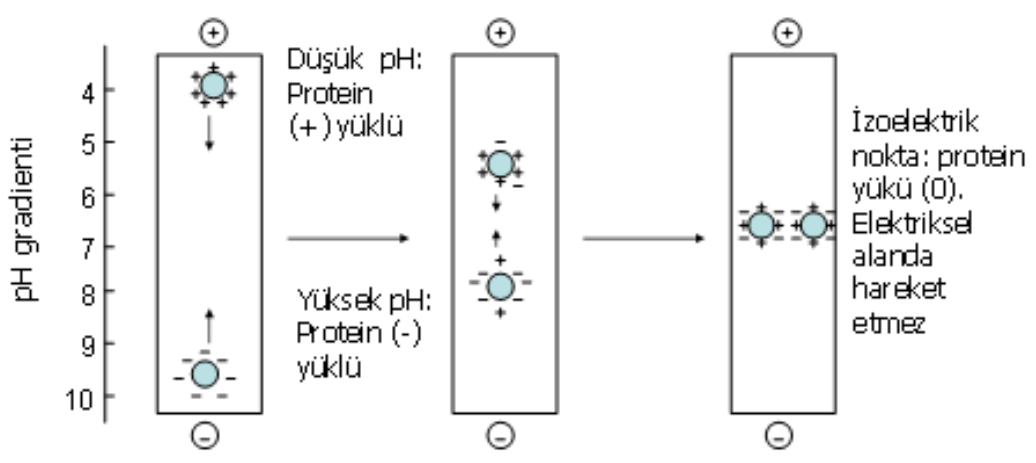

Şekil 2. İzoelektrik odaklama prensibinin şematik gösterimi 


\begin{tabular}{|c|c|c|}
\hline & $\begin{array}{l}\text { BŞEÜ Fen Bilimleri Dergisi } \\
7(1), 497-528,2020\end{array}$ & $\begin{array}{r}\text { BSEU Journal of Science } \\
\text { DOI: } 10.35193 / \text { bseufbd.667838 }\end{array}$ \\
\hline ERS & & 58-7575 (http://dergipark.gov.tr/bseufbd) \\
\hline
\end{tabular}

IEF de elektroforez için kullanılan tampon sistemi yerine, anotta kuvvetli bir asit, katotta da kuvvetli bir baz kullanılır. Jel ortamına da gerektiği kadar amfolit solüsyonu katılır. Sisteme akım verilir ve amfolitler pI ya göre jelde düzenlenirler. En asidik olan anoda, en bazik olan da katoda doğru ilerler. Bunun sonucu jel içinde anottan katoda doğru artan, 2,5-11 arasında bir pH gradyenti oluşur. Bu basamak, agaroz veya poliakrilamid jel gibi büyük porlu bir ortamda gerçekleştirilir. Bir proteinin çözünürlüğü pI noktasında minimum olduğu ve protein molekülü bu pH değerinde net bir yük taşımadığı için elektrik alanında hareket edemez. Dolayısıyla IEF jeline uygulanan örnekteki proteinler, jel üzerinde net yüklerinin sıfır olduğu pH değerine kadar göç ederler ve bu noktada hareketsiz kalırlar (Şekil 2). Son yıllarda çeşitli firmalar tarafından istenilen pH aralığına sahip IEF stripleri geliştirilmiştir ve ticari olarak satılmaktadır. IEF'in strip sistemi ile gerçekleştirilmesi metodu Görg ve ark. tarafından 1988 yılında sunulmuştur [26].

Birinci boyut ayrımının proteinlerin pI değerine göre gerçekleşmesinden sonra II. boyut ayrım aşamasına geçilir. II. boyutta ayrım için genellikle lineer veya gradyent şekilli bir poliakrilamid jel kullanılır ve proteinler bu yönde molekül ağırlıklarına göre ayrılır. IEF işleminden sonra IEF tepsisinden çıkarılan IEF stripleri (jelleri) II. boyut ayrım için SDS içeren bir dengeleme tamponu ile muamele edildikten sonra bir poliakrilamid gradyent jel ile temas haline getirilir ve elektroforez işlemi başlatılır. pI noktalarına göre IEF üzerinde belli pH noktalarında toplanan proteinler II. boyuttaki ayrımda molekül büyüklüklerine göre ayrılmaktadır (Şekil 3).

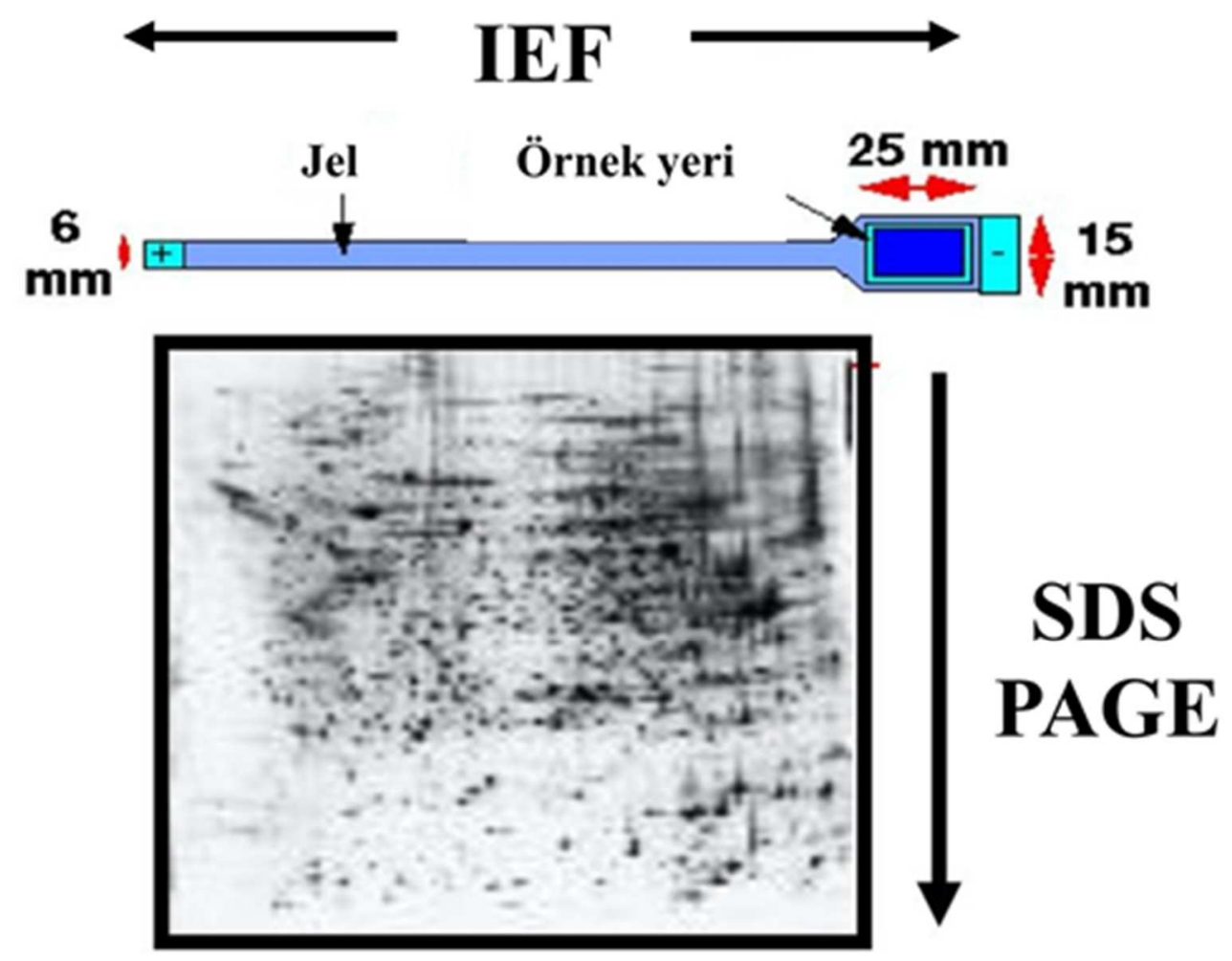

Şekil 3. 2D-PAGE'de proteinlerin iki boyutlu ayrım şeması [27]

İşlemin sonunda jel boyanarak ayrılan proteinler görünür hale getirilir. En çok kullanılan boyar madde "Coomassie blue (CBB)" dur. Daha duyarlı bir boyama tekniği ise gümüş boyamadır. Coomassie boyamayla genellikle 25-50ng civarında proteinlerin görüntülenmesi sağlanırken, gümüş boyama 5ng seviyesindeki protveinlerin tespitine izin veren daha hassas bir tekniktir. İyi bir ayrım ve boyamanın ardından tek bir jelde en az 1000 farklı proteinin görüntüsü elde edilebilmekte ve böylelikle 2 ayrı jelde farklı protein örnekleri tespit edilebilmektedir. Jel görüntülendikten sonra fotoğrafı çekilebilir, ya da densitometre ile taranarak analiz edilebilir. CBB ve gümüş boyama gibi spotların gözle görülebildiği boyama tekniklerinin kullanımı durumunda bazı 
firmalara ait çok yüksek çözünürlüklü 2 boyutlu jel tarayıcılar kullanılarak yine bu firmalara ait PDQuest, Melanie, Dymension veya Delta 2D gibi yazılımları kullanılarak jellerdeki spotlar analiz edilir. Floresan boyama tekniklerinin kullanılması durumunda ise floresan görüntüleme özelliğine sahip görüntüleme sistemleri kullanılmalıdır.

1)Yöntem: Çalışmada kullanılacak olan bitki örnekleri; kontrol ve abiyotik/biyotik stres gibi uygulama yapılmış test materyalinden oluşur. Bitkiler, uygun koşullarda yetiştirildikten sonra belli zaman aralıklarında uygun dokulardan örnek alınır ve hemen sıvı azot içerisinde dondurularak, çalışma gerçekleştirilene kadar $-80^{\circ} \mathrm{C}$ derin dondurucuda depo edilir.

\section{Total Protein Örneklerinin Hazırlanması:}

İster hayvansal materyal ister hücre hatları, mikro organizmalar isterse bitki materyali için proteomik çalışması planlanmış olsun bu çalışmaların en kritik adımı örnek hazırlığı adımıdır. Çünkü protein örneği doğru hazırlanmaz ise bütün diğer adımlardan alınacak sonuçların güvenilirliği sorgulanır. Her örnek tipi için uygun protein ekstraksiyon yöntemi çalışmalara başlanmadan önce optimize edilmelidir. Her örnek tipi için kullanılacak yöntemler amaca ve başlangıç materyal miktarına bağlı olarak değişebilmekle birlikte hayvansal sıvı ve doku örnekleri ve hücre hat örnekleri için standart yöntemler mevcuttur. Oysa bitkiler için durum farklıdır, türe ve doku tipine bağlı olarak farklı yöntemler kullanılmaktadır.

\section{Bitki Örneklerinden Protein Ekstraksiyonu}

Bitki materyalinden protein ekstraksiyon işleminde tek ve standart bir yöntem maalesef bulunmamaktadır. Bunun nedenleri şu şekilde özetlenebilir: 1. Bitkiler hayvansal organizmalardan farklı olarak hücre duvarına sahiplerdir. 2. Proteazlar açısından son derece zengin canlılardır. 3. Fenolik bileşikler polisakkaridler açısından son derece zengindirler, 4. Bitkinin farklı dokularına göre değişen yüksek bollukta proteinlere sahiptirler örneğin bitkinin yeşil kısımlarıyla çalışıldığında elde edilen total proteinlerin yaklaşık \%50'sini fotosentezde rol alan RuBisCo (Rubiloz-bifosfat karboksilaz) oluşturur. Bu durum düşük anlatım düzeyine sahip proteinlerin ve RuBisCo ile özdeş pI noktasına sahip olan proteinleri maskeler, görüntülenmesini ve tanımlanmasını engeller. Aynı şekilde kök örnekleri ile çalışılacaksa farklı depo proteinlerinin zenginliği benzer sorunlara neden olmaktadır. Dolayısı ile örnek hazırlığında kullanılan gerek mekanik gerekse kimyasal metotların bu problemleri minimum seviyeye çekecek şekilde dizayn edilmesi gerekmektedir. Bitki proteomik çalışmalarında bütün bu problemleri maksimum düzeyde bertaraf etmek amacı ile temel olarak iki protein ekstraksiyon yöntemi kullanılmaktadır. Bu yöntemler:

- TCA/Aseton Çöktürme yöntemi.

\section{- Fenol-SDS/Metanol Çöktürme yöntemi}

Her iki yöntemde de bazı kontaminantların giderilmesi için diğer bazı kimyasalların kullanımı gerekmektedir. Bunlardan polivinilpolipirolidon (PVPP), proteaz inhibitörleri, tiyoüre, ve çeşitli noniyonik deterjanlar sıklıkla bitki örneklerinden protein ekstraksiyonunda kullanılan maddelerdir.

Bitki doku ve organellerinden total protein ekstraksiyonunda en başarılı sonuçların alındığı ve tarafımızca yapılan proteomik çalışmalarda da kullanılan TCA/Aseton ile çöktürme ve Fenol-SDS/Metanol yöntemi ile ekstraksiyon yöntemleri detaylı olarak aşağıda verilmiştir. Bu yöntem temel [9] alınarak uygulanmaktadır.

\section{TCA/Aseton Çöktürme yöntemi [9]}

$\mathrm{Bu}$ yöntem bitki dokulardan protein ekstraksiyonu için kullanılabilir ve işlem soğukta $\left(0-+4^{\circ} \mathrm{C}\right)$ de gerçekleştirilmelidir. Yöntemin uygulanışı sırasında kullanılan solüsyon ve kimyasallar şöyledir;

TCA/aseton çözeltisi: Soğuk aseton içerisinde \% 0,07 (w/v) 1,4-Ditiyotreitol (DTT) ve \% 10 (w/v) TCA çözündürülerek hazırlanır ve kullanılıncaya kadar $-20^{\circ} \mathrm{C}$ de saklanır.

Yıkama çözeltisi: \% 0,07 (w/v) DTT içeren soğuk aseton çözeltisi . 
IEF çözeltisi: 7M üre, 2M tiyoüre, \% 4 (w/v) CHAPS (3-[(3-Kolamidopropil) dimetilamonyo]-1-propansülfonat), 20mM DTT, \% 1 (w/v) amfolit pH 3-10.

Amaca uygun koşullarda yetiştirilmiş bitki materyali (yaprak, sap, kök vb) hasat edilir edilmez hemen sıv1 azota alınarak dondurulur. Eğer örrnek hemen kullanılmayacaksa $-80^{\circ} \mathrm{C}$ de saklanır. Uygun ebatlardaki steril havan ve havan kolları, değişik büyüklüklerde spatüller $-20^{\circ} \mathrm{C}$ 'de kullanılana kadar depolanır. İşlem esnasında bu spatüller sivı azot ortamında tutulur.

Ekstraksiyondan önce çalışılacak alan önce normal şekilde temizlendikten sonra \%70 alkol ile silinir. $20^{\circ} \mathrm{C}$ de ki havan-havan kolu çıkarılarak sıvı azot ile soğutulur ve içinde sıvı azot var iken minimum $1 \mathrm{~g}$ bitki materyali havan içerisine konarak kontaminasyonu ve/veya protein kararlılığının korunması için gerekli proteaz inhibitörleri gibi maddeler de eklenerek havan içerisindeki bitki materyali, sık sık azot ilavesi yapılarak, havan kolu yardımıyla 25-30 dakika örneğin erimesine izin vermeden çok ince toz haline getirilir (havan içerisindeki örnek beyaza yakın renk aldığında öğütme işlemi tamamlanmış demektir).

Öğütme işlemi tamamlanır tamamlanmaz havan içeriği $8-10 \mathrm{~mL}$ (1g bitki materyali için) soğuk TCA/Aseton çözeltisi içeren santrifüj tüpüne alınarak hızlı bir şekilde soğukta 1 dakika boyunca vortekslenir.

Elde edilen örnek süspansiyonu $-20^{\circ} \mathrm{C}$ de çökmeye bırakılır. $-20^{\circ} \mathrm{C}$ deki inkübasyon sırasında her 15 dakikada bir örnek 30 saniye şiddetlice vortekslenir ve tekrar $-20^{\circ} \mathrm{C}^{\prime}$ ye bırakılır. Bu işlem 6-8 saat boyunca tekrarlanır ve örnekler gece boyu $-20^{\circ} \mathrm{C}$ 'ye bırakılır. Ertesi gün çökmeye bırakılan örnekler $12.000 x g$ de 20 dakika $4^{\circ} \mathrm{C}$ de santrifüjlenir. Süpernatant atılır ve bitki materyalindeki total proteini içeren çökelti (pellet) $10 \mathrm{~mL}$ soğuk yıkama çözeltisi eklenerek ve 30 saniye vortekslendikten sonra $-20^{\circ} \mathrm{C}$ de 10 dakika inkübe edilir ve yukarıdaki gibi santrifüj edilir. Süpernatant atılır, bu işlem 6-8 defa tekrarlanır (buradaki kriter süpernatantın berrak olması yani klorofil ve benzeri bitki pigmentlerinin mümkün olduğunca uzaklaştırılmasıdır). Elde edilen Pellet "Acetonepowdered" protein olarak isimlendirilmektedir. Ama bu elde edilen pellet sadece proteinden ibaret değildir aynı zamanda diğer hücresel kalıntıları da içermektedir. Pellet inert gaz ortamında kurutulur (bu aşamada tam kurutma önerilmez).

Kuru pellette bulunan protein içeriği IEF çözeltisi (7M üre, 2M tiyoüre, \% 4 (w/v) CHAPS,20mM DTT, \% 1 (w/v) amfolit pH 3-10) ile çözünür hale getirilir. Bu işlem yaklaşık 3-4 saat kadar çözünürleştirme çözeltisinde orbital karıştırıcı üzerinde 250RPM de oda sıcaklığında inkübasyonu gerektirmektedir. Bu işlem sırasında örnek 3-4 defa buz üzerinde ultrasonik banyoda 1 er dakikalık periyotlar halinde tutulur. İnkübasyondan sonra örnek $30.000 \mathrm{xg}$ de $20^{\circ} \mathrm{C}$ de 30 dakika santrifüjlenir $\left(20^{\circ} \mathrm{C}\right.$ nin altındaki sıcaklıklarda üre kristallenir). Bu aşamada süpernatant hacmine uygun steril bir tüpe aktarılır. Protein ekstraksiyonu sırasında ayıramayan küçük nükleotid parçalarını uzaklaştırmak için $100.000 \mathrm{xg} 1$ saat $20^{\circ} \mathrm{C}$ de santrifüj edilir. Uzaklaştırılamayan nükleotid parçaları, 2D-PAGE te IEF işlemi sırasında örneğin jele girmesini engelleyerek IEF işleminin başarısını düşürür. Bu işlemle protein örneği berrak bir hale gelir (Ultra santrifüje ulaşım imkânı varsa bu adımın atlanmaması önerilir çünkü bu adım elde edilecek proteinin kalitesi ve sayısını arttırmaktadır).

Elde edilen protein derin dondurucuya kaldırılmadan önce kantitatif olarak protein miktarı tayin edilmelidir. Protein tayini için bikinkoninik asit yöntemi, Lowry yöntemi, Bradford yöntemlerinden biri kullanılabilir. Ancak protein çözünürleştirmek için kullanılan IEF çözeltisindeki kimyasallara en yüksek toleransı gösteren Bradford yöntemidir. Protein tayin işleminde hem standartlar hem de örnekler en az 2 tekrarlı çalışılmalıdır.

\section{Fenol-SDS Metodu [27]}

$\mathrm{Bu}$ yöntem bitki ve mantar dokularından protein ekstraksiyonu için kullanılabilir. Yöntemin uygulanışı sırasında kullanılan solüsyon ve kimyasallar şöyledir;

SDS Tamponu: $\% 30$ (w/v) sukroz, \%2(w/v) SDS (Sodyum Dodesil Sülfat, 0,1M Tris.HCl pH8,0 ve 1mM PMSF (Fenil Metil Sülfonil Florür).

Fenol Solüsyonu: Tris ile doyurulmuş (Sigma, USA) 
Amonyum asetat/metanol çözeltisi: 0,1M amonyum asetat mutlak metanol içerisinde hazırlanır ve $-20 \mathrm{oC}$ de saklanır.

Protein Çözünürleştirme Tamponu: (7M üre (Sigma, USA), 2M tiyoüre (Sigma, USA), \%4(w/v) CHAPS (3-[(3Kolamidopropil) dimetilamino]-1-propansülfonat) (Sigma, USA), 30mM DTT (Merck, USA).Bitki materyali tartılarak sıvı azot yardımı ile havanda yaklaşık 1 saat çok ince toz haline getirilir. Ezme işlemini takiben çok ince toz haline getirilen bitki dokusu, ağırlığının 3 katı soğuk SDS-Tamponu içeren tüp içerisine alınır. Daha sonra bu karışım ultrasonik banyoda 6 defa 15 saniye buz içerisinde sonikasyon işlemine tabi tutulur. Sonikasyon sonrasında elde edilen örnek süspansiyonu üzerine başlangıç SDS-tamponuna eşit hacimde Tris ile doyurulmuş Fenol Solüsyonu eklenerek $+4^{0} \mathrm{C}^{\prime}$ de 10 dakika vortekslenir. Vorteks işleminden sonra çözelti santrifüj tüplerine alınarak 8.000 xgde 10 dakika $+4^{0} C^{\prime}$ de santrifüj yapılır. Santrifüj sonrasında proteini içeren en üstteki fenolik faz ayrı bir temiz tüpe alınarak alttaki pellet (katı) faza tekrar aynı miktar fenol katılarak ekstraksiyon işlemi tekrarlanır, elde edilen fenolik fazlar birleştirilir. Bu toplanan fenolik fazın üzerine toplam hacmi kadar SDStampon eklenerek 3-10 dakika soğukta karıştırılır. 8.000xg'de 10 dakika $+4^{0} \mathrm{C}$ 'de santrifüj yapılır, süpernatant temiz bir santrifüj tüpüne alınarak hacminin 3 katı kadar soğuk $0,1 \mathrm{M}$ amonyum asetat/metanol çözeltisi eklenerek bir gece boyunca (16-18 saat) $-20^{\circ} \mathrm{C}^{\prime}$ de çökmeye bırakılır. Bir sonraki gün $-20^{\circ} \mathrm{C}$ 'den çıkartılan örnekler $10.000 x g$ 'de 30 dakika $+4^{0} \mathrm{C}$ ' de santrifüj yapılır ve bu işlem 6 defa tekrarlanır. 6 . santrifüjden sonra süpernatant kısmı atılır ve pellet kısmı alınarak \% 0,07 (w/v) DTT (1,4-Ditiyotreitol) (Merck, USA) içeren aseton ile muamele edilerek 10.000xg de 30 dakika $+4^{0} \mathrm{C}$ 'de santrifüj yapılır. Süpernatant kısmı atılır ve elde edilen saf proteinlerin bulunduğu pellet kısmı azot gazı altında kurumaya bırakılır. Elde edilen protein, çözünürleştirme tamponu ile süspanse edilir ve pipet ile al-ver yaparak soğukta 1 saat boyunca maksimum çözünürlüğü elde etmek için yavaşça karıştırılır. Proteinlerin çözünmesini arttırmak için $6 \mathrm{kez} 15$ saniye soğukta sonike edilir ve 30.000xg'de 30 dakika $+4^{0} \mathrm{C}$ 'de santrifüjlenir. Protein içeren süpernatant temiz bir tüpe alınır. Örneklerden elde edilen protein konsantrasyonu Bradford Reaktifi veya yukarıda adını saydığımız metotlardan biri ile tayin edilir. Elde edilen protein viallere bölünerek $-80^{\circ} \mathrm{C}$ de saklanır.

\section{Proteinlerin İki Boyutlu Ayrımı}

\section{IEF İşlemi (1. Boyut)}

IEF işleminde kullanılan jel çubukları plastik bir yüzeye ko-polimerize edilmiş olan akrilamid bazlı jellerdir ve $0,5 \mathrm{~mm}$ kalınlığında kuru halde ticari olarak temin edilmektedir. Stripler kullanılacağı ana kadar $20^{\circ} \mathrm{C}$ 'de depolanmalıdır (bu stripler $-20^{\circ} \mathrm{C}$ 'den çıkarılır çıkarılmaz 10 dakika içerisinde kullanılmalıdır) ve kullanılmadan önce rehidrasyon yapılmalıdır. Rehidarasyon işlemi sonucunda jel kalınlığı orjinal kalınlığı olan $3 \mathrm{~mm}$ ye ulaşır.

Rehidrasyon işlemi, jel çubukları 7M üre, 2M tiyoüre, 20mM DTT, $\% 2$ CHAPS ve \%1 amfolit içeren çözelti içerisinde $10-12$ saat $+20^{\circ} \mathrm{C}$ 'de inkübasyonu ile gerçekleştirilir. Rehidrasyon işlemi örnekli veya örneksiz olarak ve aktif veya pasif olarak uygulanır. Jel çubukları rehidrasyon çözeltisinde çözünmüş protein örneği rehidrasyon tepsisi içerisindeki kuyulara yerleştirilerek üzeri mineral yağla kaplanır ve inkübasyon işlemi uygulanır. Eğer işlem sırasında düşük voltaj $(50 \mathrm{~V})$ da uygulanırsa bu işleme örnekli aktif rehidrasyon denir. Uygulanmaz ise örnekli pasif rehidrasyon denir. Genel olarak örnekli pasif rehidrasyonu önerilmektedir.

Rehidrasyon işlemini takiben IEF izoelektrik odaklama (IPGphor3GE Healthcare) cihazında bulunan odaklama tepsisinin kuyularına rehidrate edilen jel çubukları yerleştirilir ve çubukların + ve - uçlarına $150 \mu \mathrm{L}$ saf su ile ıslatılmış elektrod kağıtları yerleştirilir. Mineral yağ (Merck, USA) jelli ve jelsiz bütün kuyulara eklenir (toplam 108mL) ve elektroforez işlemi başlatılır. IEF koşulları Tablo 1.'de verilmiştir. 
Tablo 1. IEF Koşulları*

\begin{tabular}{lcccc}
\hline Step & & {$[\mathbf{V}]$} & süre & Vh \\
\hline $\mathbf{1}$ & Step & 100 & $00: 30$ & \\
$\mathbf{2}$ & Step & 250 & 250 & Vh \\
$\mathbf{3}$ & Grad & 500 & 500 & Vh \\
$\mathbf{4}$ & Grad & 1000 & 1500 & Vh \\
$\mathbf{5}$ & Grad & 10000 & 22000 & Vh \\
$\mathbf{6}$ & Step & 10000 & 50000 & Vh \\
$\mathbf{7}$ & Step & 100 & $10: 00$ & HH:mm \\
\hline
\end{tabular}

*Bu koşullar, 4-7 pH gradyentine sahip 24cm lik IPG jel çubukları için optimizedir, her örnek ve kullanılan pH gradyenti ve jel çubuğu uzunluğu için optimize edilmelidir.

\section{SDS-PAGE (2. Boyut)}

Dengeleme Cözeltisi 1:50mM Tris.HCl pH 8,8, 6M üre, \% 30 (v/v) gliserol, \%2 (w/v) SDS ve \% 1 (w/v) DTT.

Dengeleme Çözeltisi II: 50mM Tris.HCl pH 8,8, 6M üre, \% 30 (v/v) gliserol, \%2 (w/v) SDS ve \% 2,5 IAA (w/v).

Akrilamid Monomer Çözeltisi: \%29,2 Akrilamid (w/v), \%0,8 (w/v) bisakrilamid içerecek (\%30(T)) şekilde hazırlanır

Tris. $\mathrm{HCl}: 1,5 \mathrm{M} \mathrm{pH} 8,8$

SDS Çözeltisi: $\% 20(w / v)$

Amonyum peroksido sülfat (APS): \%10 (w/v)

$\underline{\mathrm{N}, \mathrm{N}, \mathrm{N}^{\prime}, \mathrm{N}^{\prime}-\text { Tetramethyl etilendiamin (TEMED) }}$

TGS (Tris Glisin SDS) Tamponu: 192mM glisin, 25mM tris, \% 0,1 (w/v) SDS

\% 0,5(w/v) Agaroz çözeltisi: 0,5g düşük erime noktalı agaroz 1XTGS içinde kaynatılarak çözülür ve sıcaklığı $70^{\circ} \mathrm{C}$ de sabit tutulur.

İzoelektrik odaklama işlemi sonunda IPG jel çubukları ikinci boyut jeli olan SDS-PAGE'e yüklenmeye uygun hale getirilmek üzere sırası ile indirgenme ve alkilasyon ajanları içeren dengeleme tamponları içinde 20 'şer dakika 150rpm'de çalkalamalı inkübatörde muamele edilir. Dengeleme işleminden sonra jel çubukları 30 saniye SDS-PAGE yürütme tamponu (TGS) ile muamele edilerek (\%10-\%20) SDS-PAGE'e yüklenir. IPG jel çubukları SDS-PAGE'e agoroz çözeltisinden 3-4mL eklenmek sureti ile sabitlenir. Elektroforez işlemi ilk 1 saatte $20 \mathrm{~mA} / \mathrm{jel}$ sonra bromfenol blue izi kaseti terk edene kadar $40 \mathrm{~mA} /$ jel olacak şekilde gerçekleştirilir. Gradyent jel çözeltisi hazırlama koşulları Tablo 2'de verildiği gibidir. Tarafımızca yapılan çalışmalarda en iyi sonuç gradyent jel kullanarak elde edilmiştir. Bu alanda çalışmaya yeni başlayanlar için \%15 akrilamid konsantrasyonlu bir jel ile başlanması önerilir. Böylece örneğin protein profili hakkında bilgi elde edilerek buna göre daha düşük konsantrasyonlu veya yüksek konsantrasyonlu jeller tercih edebilir. Gradyent jel dökmek için gradyent oluşturucu ve peristaltik pompaya sahip olunmalıdır. 


\begin{tabular}{|c|c|c|}
\hline & $\begin{array}{l}\text { BŞEÜ Fen Bilimleri Dergisi } \\
7(1), 497-528,2020\end{array}$ & $\begin{array}{r}\text { BSEU Journal of Science } \\
\text { DOI: } 10.35193 / \text { bseufbd.667838 }\end{array}$ \\
\hline ERS & & 58-7575 (http://dergipark.gov.tr/bseufbd) \\
\hline
\end{tabular}

Tablo 2. Gradyent Jel Çözeltisi Hazırlanış*

\begin{tabular}{ccc}
\hline Kullanılan Maddeler & $\begin{array}{c}\text { \%10 Konsantrasyon (az yoğun jel } \\
\text { karışımı) } 275 \mathbf{m L}\end{array}$ & $\begin{array}{c}\text { \% 20 Konsantrasyon (çok yoğun jel } \\
\text { karışımı) 275mL }\end{array}$ \\
\hline Akrilamid-Bisakrilamid & $92 \mathrm{~mL}$ & $183 \mathrm{~mL}$ \\
$1,5 \mathrm{mM}$ Tris.HCl pH 8,8 & $69 \mathrm{~mL}$ & $69 \mathrm{~mL}$ \\
Milliq Su & $110 \mathrm{~mL}$ & $1,2 \mathrm{~mL}$ \\
\%20 SDS & $1,38 \mathrm{~mL}$ & $1,38 \mathrm{~mL}$ \\
Gliserol & - & $19 \mathrm{~mL}$ \\
\%10 APS (10/100 w/v) & $2,75 \mathrm{~mL}$ & $1,4 \mathrm{~mL}$ \\
\%100 TEMED & $47 \mu \mathrm{L}$ & $8 \mu \mathrm{L}$ \\
\hline
\end{tabular}

*Tabloda verilen hacimler 20x25x0,15cm'lik jel kasetleri (24cm'lik IPG jel çubukları) içindir.

\section{Jel Görüntüleme İslemi}

Protein miktarına bağlı olarak yaygın olarak kullanılan yöntemler Comassie Brilliant Blue, Gümüş Boyama teknikleri, floresan boyalar kullanılabilir. Bu teknikler arasında hassasiyeti en yüksek olan teknik floresan boyama teknikleridir ki standart 10X10X0,15cm' lik bir SDS-PAGE için yaklaşı1k $5 \mu \mathrm{g}$ protein miktarı ile başlamak yeterlidir fakat bu boyalar pahalıdır ayrıca görünür hale getirmek için de özel görüntüleme araçlarına gereksinim vardır. Gümüş boyama yönteminin hassasiyeti gümüş boyama protokolüne bağlı olarak $0,25 \mathrm{ng}$ 'a kadar düşebilmektedir. 2D-PAGE analizlerinde gümüş boyama ile sonuç alabilmek için IPG jel çubuklarına yüklenmesi gereken optimum protein miktarı $200 \mu \mathrm{g}$ 'dır fakat $100 \mu \mathrm{g}$ ile de jelde protein spotları görülebilir.

Gümüş boyama tekniği her ne kadar hassasiyeti yüksek olduğu için tercih edilebilir görünse de gümüş boyama kitlerinin raf ömürlerinin kısalı̆̆ı ve daha da önemlisi proteinlerin yanı sıra nükleotidlerin de boyanma ve sanki protein spotu gibi değerlendirilebilme riski yöntemin dezavantajlarıdır. Bu nedenle CBB boyama tekniği önerilmektedir. Bu boyama yönteminde 2 teknik kullanılmaktadır;

1. Asetikasit-metanol çözücü sisteminde çözünmüş CBB R250'nin kullanıldı̆̆ı yöntem: standart SDSPAGE analizlerinin yapıldığı laboratuvarlarda rutinde kullanılmaktadır. Hassasiyeti gümüş boyamadan düşüktür fakat hızlı bir yöntemdir, maksimum 2-3 saat içerisinde sonuç gözlenebilir.

2. Kollaidal CBB tekniği: bu yöntemin hassasiyeti neredeyse gümüş boyama hassasiyetine yakındır. Bu teknikte koloidal boya çeşitli şekillerde hazırlanabilir. Yaygın kullanılanı Neuhoff ve ark. tarafından geliştirilen [28] CBB G250'nin kullanıldığı amonyum sülfat/fosforik asit çözücü siteminin kullanıldığı yöntemdir. Bu yöntem boya çıkarılma süreçlerinde $\mathrm{pH}$ bağımlı bir işlemdir ve 4 farklı çözelti kullanılır. Görüntüleme işlemi 2 günde tamamlanır. Hassasiyeti arttırmak için 3 kez tekrarlanması önerilir. Tarafımızca yapılan BTH (Benzathiadiazole) stresinde buğday da proteom farklılaşmasının tanımlandığı [11] çalışmada bu yöntem kullanılmıştır (Şekil 4). Yine tarafımızca yapılan ve henüz yayınlanma sürecinde olan arpada külleme hastalığında gerçekleştirilen proteomik çalışmada ve halihazırda yürütülen çalışmalarımızda da ise TCA içerisinde CBB R250 boyasının çözülerek hazırlandığı koloidal boyama tekniklerini kullanılmaktadır. 


\begin{tabular}{|c|c|c|}
\hline & $\begin{array}{l}\text { BŞEÜ Fen Bilimleri Dergisi } \\
7(1), 497-528,2020\end{array}$ & $\begin{array}{r}\text { BSEU Journal of Science } \\
\text { DOI: } 10.35193 / \text { bseufbd.667838 }\end{array}$ \\
\hline ERS & & 8-7575 (http://dergipark.gov.tr/bseufbd) \\
\hline
\end{tabular}

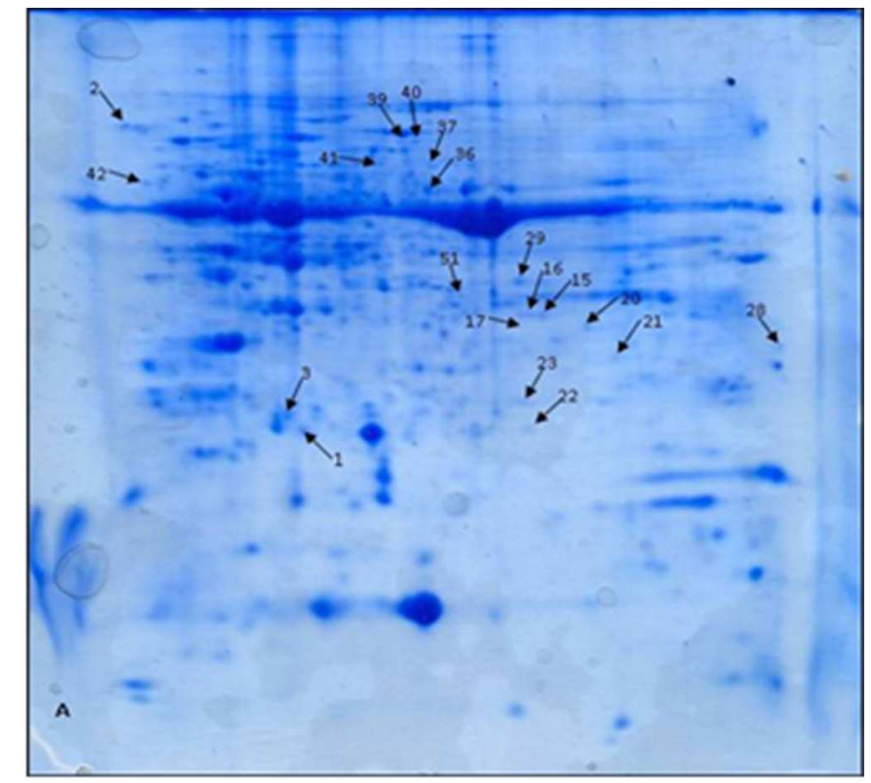

Şekil 4. BTH stresine maruz bırakılmış buğday proteom çalışmasında kontrol bitkilerine ait II. boyut jel görüntüsü [11].

Kollaidal Coomassie Blue Yönteminin hassasiyeti yine gümüş boyama kadar iyi olan bir boyama tekniğidir, MS analizleri ile uyumludur ayrıca fosforik asit içermediğinden fosforilasyon modifikasyonları zenginleştirme yapılmamış örneklerde bile kullanılabilir. Fakat fosforik asit içeren CBB boyamalarında bulunan fosforilasyon modifikasyonları boyadan kaynaklanabileceğinden sonuca daha dikkatli yaklaşılmalı ve muhakkak valide edilmelidir. Boyama ve boya giderme işlemlerinden sonra jellerin dijital ortama aktarılması yani jel spot analizi yapılmalidir.

\section{Jel Spot Analizi}

İki boyutlu jeller ayrıştırılan proteinlere ait spotların dijital ortama aktarılmasında yüksek çözünürlüklü özel jel tarayıcılar kullanılmalıdır. Bu tarayıcılar Biorad, GE Healthcare, SynGene gibi firmalardan temin edilebilir. Piyasada başka tarayıcılara ulaşılabilirse de isimlerini saydıklarımız en güvenilir alanda en çok kullanımı tercih edilenlerdir. Ayrıca jel spot analizlerinin (image analysis) gerçekleştirebileceği 2D-PAGE analizine spesifik yazılımların kullanılması özellikle karşılaştırılmalı proteomik çalışmalarda önemlidir. Bununla birlikte proteom haritalarının çıkarılmasında da gereklidir. Çünkü biyolojik örneklerle çalışılırken mutlaka en az 3 biyolojik tekrarın ve her biyolojik tekrar için de 3 analitik tekrarın yapılması gerekir. Analitik tekrarın yapılma nedeni deneysel(pipetleme, kimyasal malzeme de değişiklik gibi) süreçte meydana gelebilecek hata veya varyasyonları bertaraf etmek iken, biyolojik tekrarlar ise canlının kendisinden kaynaklanan varyasyonları göz önünde bulundurabilmek için gereklidir. Jel spot analizi için Delta 2D (Decodon), PDQuest (Biorad), imagemaster 2D platinium, Melani (GE healthcare) ve Dymension 2 (Syngene) yazılımları yaygın kullanılan ve güvenilir yazılımlardır. Bu yazılımlar arasında Delta 2D, Melanie, PDQuest ve Dymension 2 yazılımları tarafımızca kullanılmış olup en kullanıcı dostu ve anlaşılması kolay olanın Delta 2D olduğu gözlenmişdir. Aynı derecede rahat kullanılanlardan bir diğer yazılım ise Dymension yazılımıdır.

Dolayısı ile eğer tasarlanan deney, A kimyasalı/maddesi/organizması ile muamele edilmiş bir bitki örneğinin kontrol bitkisi ile karşılaştırmasına dayanıyor ve deney 3 biyolojik tekrarlı olarak yapılıyor ise çalışma sonunda değerlendirmeye alınan kontrole ait 9 jel ve muamele edilmiş bitkiye ait 9 jel olacaktır. Bu durumda;

1. Jel görüntülerinin tarayıcı yardımı ile dijitalize edilmesini takiben önce kontrol jelleri sisteme yüklenir sonra muamele edilmiş örneklere ait jeller sisteme yüklenir veya tersi. 


\begin{tabular}{|c|c|c|}
\hline & $\begin{array}{l}\text { BŞEÜ Fen Bilimleri Dergisi } \\
7(1), 497-528,2020\end{array}$ & $\begin{array}{r}\text { BSEU Journal of Science } \\
\text { DOI: } 10.35193 / \text { bseufbd.667838 }\end{array}$ \\
\hline $\begin{array}{l}\mathrm{E} \\
\mathrm{R}\end{array}$ & & 88-7575 (http://dergipark.gov.tr/bseufbd) \\
\hline
\end{tabular}

2. Yükleme işlemi bittikten sonra normalizasyon işlemi gerçekleştirilir. Bu işlem çok önemlidir çünkü boyanma dolayısı ile jel arka planlarının eşitlenmesi gerekir aksi taktirde spotların \% hacimleri veya yoğunlukları her bir jelde farklılık taşıyacaktır dolayısı ile de kantitatif bir çalışma ve sonuç elde edilemeyecektir.

3. Normalizasyon işleminden sonra kontrol ve muamele edilmiş test grubundaki ortak spot sayısı program tarafından ayrı ayrı sayılır. Jeller birbirleri ile karşılaş̧ırılır. Bu karşılaştırma sonucunda, programda spot yoğunluğunu mu yoksa hacminin mi baz alınarak analiz yapılacağının belirtilmesi için sonuçlar \% hacim veya spot yoğunluğu olarak verilir. Yazılımlar çeşitli istatistik programlar içermekle birlikte araştırmacının, amacına uygun istatistiksel analizleri kendisinin yapması önerilir. sunulmuştur.

Görüntüleme işlemleri sonrasında, jel görüntülerinde jel ve spot analizlerine ait bir örnek Şekil 5'de

Kullanılan proteomik yaklaşıma göre değişmekle birlikte genel olarak karşılaştırmalı proteomik çalışmalarda, en az 1,5 kat ekspresyon artış/azalış1 eşik değer olarak kabul edilmektedir, bu değer ve üstü anlamlı olarak kabul edilmektedir.

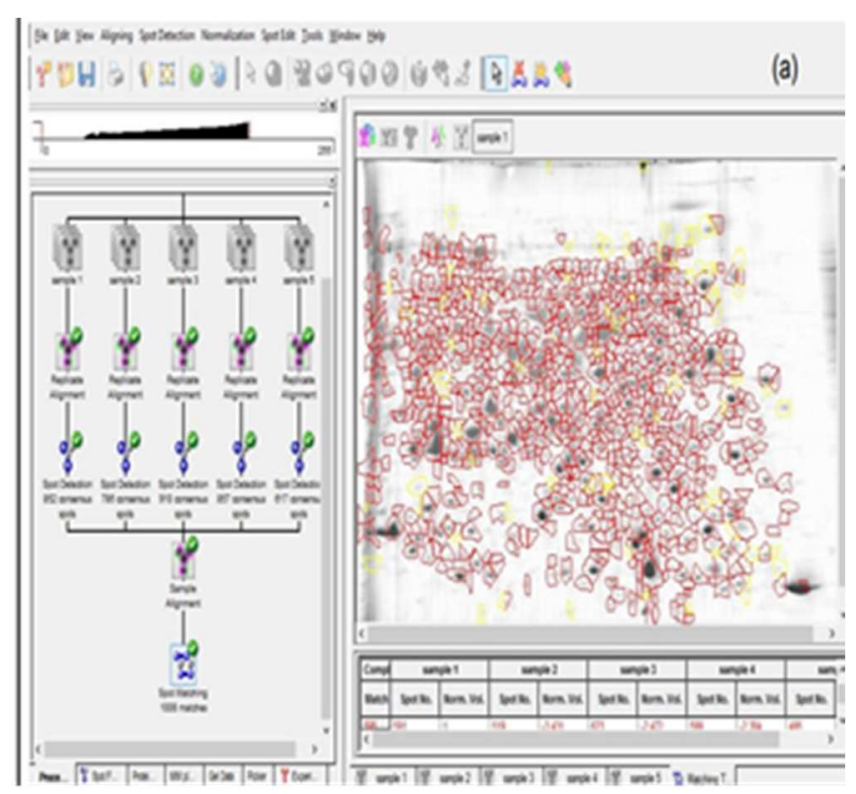

Şekil 5. Beş Biyolojik tekrar kullanılarak gerçekleştirilmiş bir çalışmamızın (Arpada ağ benek leke hastalığı etmeni proteom haritalamașı) imaj analizi (şekilden de anlaşılacağı üzere her bir biyolojik tekrar için 3 analitik tekrar yapılmıştır, kullanılan imaj analiz sistemi Syngene firmasının dır 2D-PAGE analiz yazılımı ise yine aynı firmaya ait olan Dymension 2 yazılımıdır).

\section{B.Jelsiz Yaklaşımlar:}

Bir proteomun ayrılmasında 2D-PAGE yönteminin kullanımında, kısıtlı çözünürlük, hidrofobik proteinlerin kaybı ve düşük tekrarlanabilirlik en önemli sorunlardandır. Oysa bir proteomda bulunan proteinlerin önemli bir kısmı hidrofobiktir. Bu nedenle bir hücredeki genlerin anlatımını doğru biçimde ortaya koymak için bu proteinlerin analizlerine ihtiyaç vardır ve çok daha güçlü analitik tekniklere gereksinim olduğu ortaya çıkmıştır. Jelsiz yaklaşımlar arasında son yıllarda tüm örnek tipleri için Shotgun proteomik yaklaşımların kullanımı artmıştır. Diğer taraftan 2D-PAGE tekniğinin tüm proteomik laboratuvarlarınca yaygın olarak kullanıldığı dönemlerde tanımlanabilen protein profilini genişletmek ve hassasiyeti arttırmak amacı ile dolayısıyla 2D-PAGE tekniğine alternatif olarak geliştirilen iki boyutlu sıvı kromatografi (2D-LC, two dimensional liquid chromatography) teknikleri bu proteinlerin de analizine olanak verecek nitelikte tasarlanmışlardır. Sıvı kromatografinin proteomiğe yaklaşım amacı protein karışımlarını yüksek çözünürlükte fraksiyonlara ayırarak sanal jel haritalarında görüntülemek ve protein miktar farklılıklarını ortaya koymaktır, sanal jel haritaları Şekil 6'da sunulmuştur. [29]. 
"Yüksek performanslı sıvı kromatografisi” (HPLC), hassas ayrım sağlamak üzere kısa difüzyon yoluna ve hızlandırılmış hareketli faza sahiptir. İlk modern HPLC cihazı 1965 yılında Yale Üniversitesi'nde Csaba Horvath tarafından geliştirilmiştir. Bu sistemde zamanla apolar sabit fazların ve polar hareketli fazların kullanıldığı ters faz kromatografisi ön plana çıkmıştır. Horvath ters faz kromatografisi teorisini ortaya koyarken Kirkland silika partiküllerine uzun zincirli hidrokarbon ve diğer bir grup organik molekülleri kovalent bağ ile bağlayarak bağlı sabit fazların gelişimine öncülük etmiştir.

Bugün HPLC tekniği en çok kullanılan analitik tekniklerindendir. Son yıllarda yeni nesil teknolojiler arasında yerini alan ve HPLC tekniğinin fraksiyonlama sistemi ile kombine edilmesi ile oluşturulmuş 2D-LC sistemi proteomik çalışmalar için yüksek çözünürlükte protein ayrımı sağlamak üzere geliştirilmiştir. 2D-LC ayırma tekniğinde, proteinler birinci boyutta "chromatofocusing"(CF) ile pI noktalarına göre, ikinci boyutta ise yüksek performans ters faz kromatografi (high performance reversed phase column, HPRP) ile hidrofobisite özelliklerine göre ayrıştırılarak franksiyonlanmaktadır. Sistemin bir diğer önemli özelliği 2D-LC fraksiyonlarında ayrılan proteinlerin tespiti ve örnekler arasındaki farklılıkların belirlenmesi için gelişmiş bilgisayar programlarının da sisteme dahil edilmesidir. Proteom analizleri için tasarlanan bu sistemin diğer bir avantajı da ham protein özütlerinin birkaç adımda saflaştırıldıktan sonra analiz edilmesidir. Böylece protein profillerinin karşılaştırılması sonucu elde edilen verilerin, 2D-PAGE yöntemine oranla daha tekrarlanabilir ve güvenilir olmasını sağlar. Başka bir deyişle iki boyutlu jel sistemlerinin yerine 2D-LC tekniklerinin kullanımı çok sayıda total protein örneğinin daha hızlı, güvenilir ve güçlü biçimde ayrımına imkân sağlar. Sistemin bir diğer önemli özelliği ise bir hücre/organizmaya ait proteomun önemli bir kısmını oluşturan hidrofobik yapıdaki ve pek çoğu da düzenleyici protein olan düşük anlatımlı proteinlerin, suda çözünemediği için 2D-PAGE de kaybolmasına karşın 2D-LC yöntemi ile ayrımının gerçekleştirilebilmesidir [30].

Bu derleme kapsamında yöntemsel ayrıntılar, tarafımızca kullanılan ve bir 2D-LC olan "ProteomeLab PF2D sistemi" (Protein fractination two dimensional, Beckman Coulter, ABD) 'ne dayalı olarak anlatılacaktır.

\section{1)Yöntem:}

\section{Total Protein Örneklerinin Hazırlanmasl}

Bitkinin özellikle yeşil aksamları ile yapılacak proteomik çalışmalarda RuBisCo proteinini uzaklaştıran Mg/NP40 yöntemi etkin biçimde kullanılmaktadır [32]. Bu yöntemde PEG (Polietilen glikol ) 4000'in \%15'lik konsantrasyonu ile RuBisCo proteinleri çöktürülerek büyük oranda elimine edilmektedir. "1.1 ve 1.2" başlıkları altında anlatılan diğer total protein izolasyon yöntemlerini de kullanmak mümkündür. Ancak son aşama da proteinlerin çözündürülmesi için kullanılan IEF çözeltisi yerine aşağıda detayları verilen ve PF2D sistemine uygun "Çözündürme Solüsyonu” nun kullanımı zorunludur. Mg/NP40 yönteminin detayları ve kullanılan çözeltiler şöyledir;

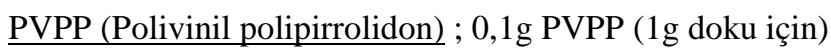

Liziz Tamponu; 0.5M TrisHCl pH 8,3 (Roche 122010), \% 2 Igepal (NP40) (Sigma I7771), 20mM MgCl 2 ( $\mathrm{Sigma}$ M8266), \% 2 Beta-Merkaptoetanol, (Applichem A1108), 1mM Fenil metil sülfonil florür (PMSF) (Sigma P7626) olacak şekilde tüm bileşenler tartılıp tek tek 50mL çift distile suda çözündürüldü ve son hacmi $100 \mathrm{~mL}$ ye tamamlanır.

\%50 PEG4000; 50g PEG4000 (Sigma 95904) 100mL çift distile suda çözündürülür.

Proteaz İnhibitör Karıșımı (Sigma P9599); $1 \mathrm{~mL}$ çift distile suda çözündürülür. $1 \mathrm{~g}$ doku için 50 $\mu \mathrm{L}$ kullanıldı.

Çözündürme Solüsyonu; 7,5M Üre (Sigma U0631), 2,5M Tiyoüre (Sigma T7875), \%12,5 Gliserol (Sigma 6279), 62,5mM Tris.HCl pH 7,8, 6,25mM Tris (2 karboksietil fosfin) (TCEP) (Sigma C4706), \%12,5 Oktil Beta -Dglukopironosid (OG) (Sigma 08001). 
Bu yöntem ile 1g yaprak dokusu 0.1g PVPP ilave edilerek, soğuk havanda sıvı azot kullanılarak iyice toz haline gelene kadar parçalanır. Toz haline getirilmiş olan yaprak dokularının üzerine 10mL liziz tamponu ilave edilir ve 10-20 dakika buzda bekletilir. Daha sonra 3000rpm de $+4^{\circ} \mathrm{C}$ de 15 dakika santirfüj edilerek protein olmayan hücre artıklarının çökmesi sağlanır ve üst faz yeni tüpe alınır. Üzerine son konsantrasyonu \% 15 olacak şekilde \%50'lik PEG4000 den ilave edilir ve 30 dakika buzda bekletilir. Bu süreçte 10 dakika aralıklarla kısa kısa vortekslenir. Süre sonunda $12.000 \mathrm{rpm}$ de $+4^{\circ} \mathrm{C}$ de 15 dakika santirfüj edilerek RuBisCo proteinlerinin çökmesi sağlanır. Üst kısım yeni tüpe alınır ve üzerine proteinlerin çökmesi için 4 hacim soğuk aseton ilave edilerek $-20^{\circ} \mathrm{C}$ de gece boyu bırakılır. Ertesi gün $14.000 \mathrm{rpm}$ de $+4^{\circ} \mathrm{C}$ de 10 dakika santrifüj edilir ve üst sıvı atılır. Protein çökeltisi pigmentlerden temizlenmek üzere 5-6 kez soğuk aseton ile yıkanır. Bunun için pellet üzerine $10 \mathrm{~mL}$ soğuk aseton ilave edilip vortekslenir ve en az 1 saat $-20^{\circ} \mathrm{C}$ de bırakıldıktan sonra $6000 \mathrm{rpm}$ 'de $+4^{\circ} \mathrm{C}$ de 10 dakika santrifüjlenerek üst sıvı atılır. Bu işlem üst sıvı renksizleşene kadar devam ettirilir. Son yıkamadan sonra protein çökeltisi aseton kokusu gidene kadar oda sıcaklığında kurutulur. Pellet kuruduktan sonra $2 \mathrm{~mL}$ çözündürme solüsyonu ve $50 \mu \mathrm{L}$ proteaz inhibitör karışımı ilave edilerek çözündürülür. Çözünmeyi arttırmak üzere $7 \mathrm{~W}$ da 5 kez 5 saniye sonikasyon uygulanır. Daha sonra 30.000xg de 30 dakika ardından da 100.000xg de 1 saat santrifüj edilerek protein olmayan moleküller uzaklaştırılır. İzole edilen proteinlerin Bradford yöntemiyle miktar tayini yapılır ve daha sonra 2 boyutlu ayrım yapılıncaya kadar $-80^{\circ} \mathrm{C}$ de muhafaza edilir.

\section{Proteinlerin İki Boyutlu Ayrımı}

İzole edilen proteinlerin iki boyutlu ayrımına ilişkin yöntemler ve detayları tarafımızca kullanılan 2D-LC sistemi (PF2D, Beckman Coulter)'ne uygun olarak anlatılmıştır. Ancak farklı cihazlarda farklı detaylar gerekmekle birlikte temel prensip itibariyle benzer adımlar kullanılmaktadır. Proteinlerin 2 boyutlu ayrımına başlanmadan önce sistemin düzgün biçimde çalışabilmesi için gerekli olan hazırlık aşamaları üretici firmanın önerdiği biçimde gerçekleştirilmelidir.

PF2D sistemi, proteinlerin farklı özelliklerini temel alarak ayırım yapan iki modülden oluşmaktadır; I. Boyut ayırım modülü, proteinleri izoelektrik noktalarına (pI) göre ayıran "High Performance Chromatofocusing Fractionation" (HPCF) kolonu taşır. Bu modülde pH gradyenti (8.5-4.0) oluşturularak proteinler pI noktalarına göre ayrılmaktadır.

Birinci Boyut Ayrum:

Kullanılan solüsyonlar;

Bașlangıç Tamponu (BT): 6M üre, 25mM Bis-Tris (Sigma 14879) ve \%0,2 OG, ultra saf suda çözülür (pH 8,5, pH amonyum hidroksit ile ayarlanır).

Elüsyon Tamponu (ET): 6M Üre, \%10-12,5 v/v Polybuffer ve \%0,2 OG ultra saf suda çözündürülür (pH ayarı iminodiasetik asit ile yapılır ve 4,0 'e ayarlanır).

Yüksek iyonik kuvvetli solüsyon (HISS): $1 \mathrm{M} \mathrm{NaCl}$ (ultra saf suda çözündürülür).

\section{$\underline{\text { HPLC'ye uygun su }}$}

Proteinlerin 1. boyut ayırımında, sağlıklı bir $\mathrm{pH}$ gradyentinin oluşturulması son derece önemli olduğundan, pH gradyent tamponları olan BT ve ET'lerin hazırlanmasına büyük özen gösterilmelidir ve karşılaştırma yapılacak örnekler için aynı BT ve ET tamponlar kullanılmalıdır.

İzole edilen proteinlerin PF2D sistemine yüklenmeden önce sistemle uyumlu olan BT içine alınması ve tuzlardan temizlenmesi gerekmektedir. Bu amaçla $-80^{\circ} \mathrm{C}$ de muhafaza edilen örnekler oda sıcaklığına getirildikten sonra PD-10 (GE Healthcare, W396289) kolondan geçirilir. PD-10 kolonun alt ucu kesilerek açılır ve kolondan 25mL BT geçirilerek dengelenir. Daha sonra oda sıcaklığına getirilen örneklerin hacmi aynı buffer ile $2,5 \mathrm{~mL}$ ye tamamlanıp kolona yüklenir. Örnek tamamen kolondan geçtikten sonra 3,5mL BT kolona ilave edilir ve temiz bir tüpte toplam 3,5mL BT içinde geri kazanılan örneklerdeki protein miktarı bikinkoninik asit (BCA), (Sigma) analizi ile belirlenir. 


\begin{tabular}{|c|c|c|}
\hline & $\begin{array}{l}\text { BŞEÜ Fen Bilimleri Dergisi } \\
7(1), 497-528,2020\end{array}$ & $\begin{array}{r}\text { BSEU Journal of Science } \\
\text { DOI: } 10.35193 / \text { bseufbd.667838 }\end{array}$ \\
\hline $\begin{array}{l}\mathrm{E} \\
\mathrm{R}\end{array}$ & & 88-7575 (http://dergipark.gov.tr/bseufbd) \\
\hline
\end{tabular}

PF2D sisteminin gerekli tüm hazırlıkları tamamlanıp I. ve II. boyut kolonları dengelendikten sonra, PD10 kolondan geçirilen ve konsantrasyonu belirlenen protein örneklerinden yaklaşık olarak 2-3mg örnek sistemin I. boyutuna yüklenir. Yükleme işlemi üretici firma talimatları uygulanarak gerçekleştirilir. Karşılaştırma yapılacak örnekler için eşit miktarda protein yüklenmesine özen gösterilmeli ve örnek yükleme aşamasında sisteme hava kabarcığının verilmemesine dikkat edilmelidir. Yükleme işlemi bittikten sonra cihaz, I. boyut analizine başlar ve sisteme yüklenen total protein karışımındaki her bir proteini "chromatofocusing "(CF) kolonundan geçerken izoelektrik noktasına (pI) göre ayırır. Bu aşamada izoelektrik noktasına göre ayrımın sağlanabilmesi için kolon içinde 8,5 pH dan başlayarak 4,0'e doğru azalan bir $\mathrm{pH}$ gradyenti oluşturulmaktadır. Bu süreçte kolondan geçen proteinler kendi izoelektrik noktaları ve kolon içindeki $\mathrm{pH}$ değerine göre kolondan itilmekte veya alıkonmaktadır. Başka bir deyişle kolondan geçen proteinlerin ayrımı pI değerlerinin kolon içi pH'sına göre yüksek, düşük veya aynı değerde oluşuna göre gerçekleşmektedir. Ayırma prensibi Şekil 6 de şematize edilmiştir. Protein örneği, sisteme yüklendikten sonra ilk 20-40 dakika kolondan sadece BT (pH 8,5) geçişi gerçekleşmekte, bu süreçte pI s1 8,5 'dan büyük olan bazik proteinler kolondan itilerek zamana bağlı olarak fraksiyonlanmaktadır. Süre sonunda sistem yavaş yavaş pH değeri 4,0 olan ET akışını başlatmaktadır. Böylece metot da belirtilen süreye bağlı olarak I. boyut kolonunun iç pH sı, 8,5 dan 4,0 e kadar yavaş yavaş düşürülmektedir. Gradyent sırasında proteinin pI değeri kolon içi pH sından yüksek ise kolondan atılmakta, aynı değere sahip ise kolonda asılı kalmakta ve eğer düşükse kolon iç yüzeyinde tutuklanmaktadır (Şekil 6).

Kolondan çıkan her proteinin 280nm deki absorbans değeri bir dedektörle ölçülür ve her 0,3 pH aralıkta yer alan proteinler 96 kuyulu mikroplakalara otomatik olarak fraksiyonlanır. 280nm de proteinlerin absorbans değerleri sistemin yazılımı tarafından proteinlerin varlığı ve miktarını gösteren I. boyut kromatograma dönüştürülür. BT geçişi durup tamamen ET geçişi gerçekleştiğinde ise kolon içi pH s1 4,0'e indirilmiş olur. Sadece ET geçişinin olduğu son 20 dakika boyunca da zamana bağlı olarak asidik proteinlerin ayrımı gerçekleştirilmektedir. pH gradyenti tamamlandıktan sonra HISS solüsyonu ile kolon yıkanır.

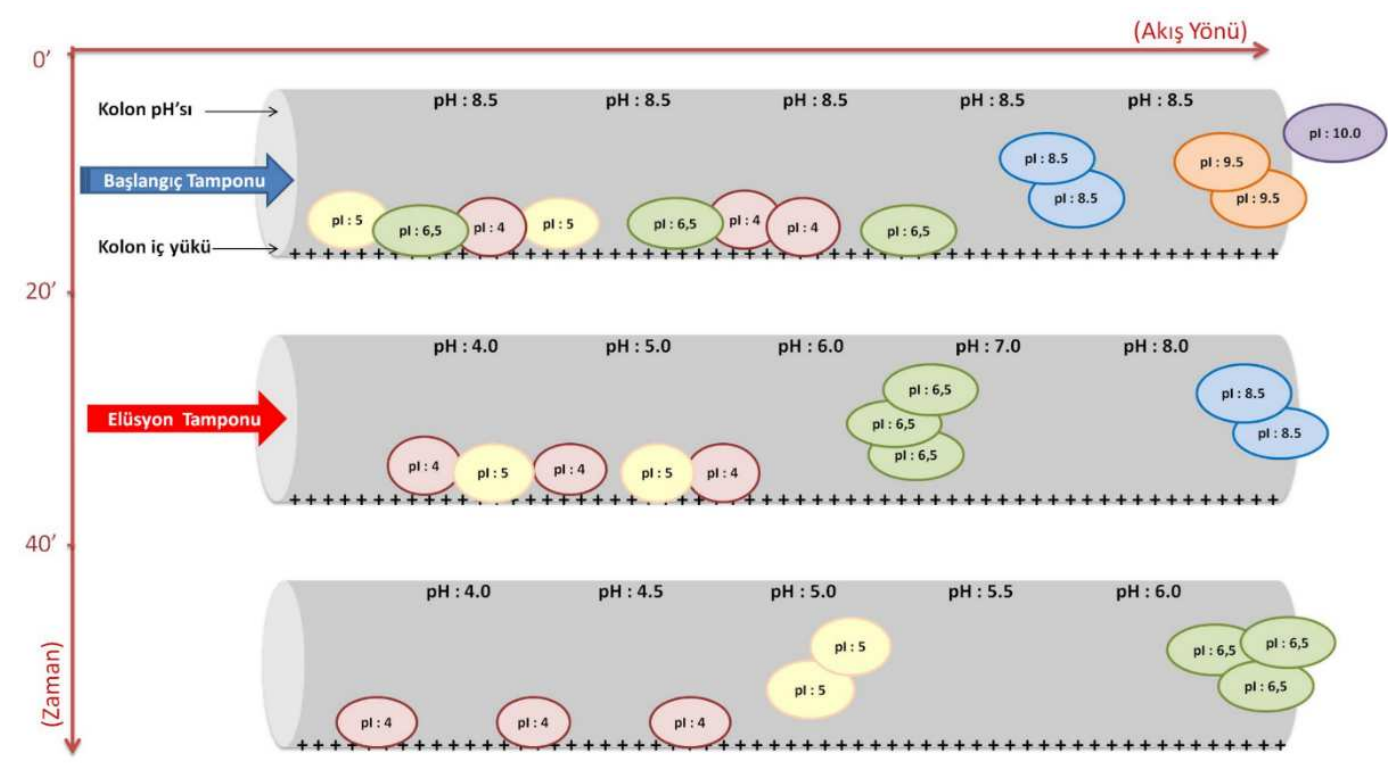

Şekil 6. Birinci boyut kolonda proteinlerin pI noktalarına göre ayırımı (Proteinlerin pI değeri 1) kolon içi pH sından düşükse, proteinler kolon iç yüzeyinde tutuklanmaktadır, 2) kolon içi pH sı ile aynı değere sahip ise proteinler kolonda asılı kalmakta, 3) kolon içi pH sından yüksek ise proteinler kolondan atılmaktadir)

\section{İkinci Boyut Ayrım:}

Sistemin 2. modülünde proteinler hidrofobisitelerine göre ayrılmaktadır. Bu nedenle oluşturulacak hidrofobisite gradyenti için su ve asetonitril kullanılmaktadır. Bu solüsyonlara iyon baskılayıcı ajan olarak trifloroasetik asit (TFA) ilave edilir. 


\begin{tabular}{|c|c|c|}
\hline & $\begin{array}{l}\text { BŞEÜ Fen Bilimleri Dergisi } \\
7(1), 497-528,2020\end{array}$ & $\begin{array}{r}\text { BSEU Journal of Science } \\
\text { DOI: } 10.35193 / \text { bseufbd.667838 }\end{array}$ \\
\hline ERS & & 8-7575 (http://dergipark.gov.tr/bseufbd) \\
\hline
\end{tabular}

Birinci boyut kromatogram incelenerek II. Boyut ayrımı uygun görülen fraksiyonlar belirlenir. Sistemin yazılımı kullanılarak bu fraksiyonların II. Boyut ayrımı için komut verilir. Sistem tarafından 96 kuyulu mikroplakalarda toplanan bu fraksiyonların her birinden $200 \mu \mathrm{L} 2$. boyut ayırım için otomatik olarak HPRP modülüne transfer edilir. Kolon sicaklığ $50^{\circ} \mathrm{C}$ 'de tutulur Her bir fraksiyonda yer alan proteinler, hidrofobisite özellikleri temel alınarak HPRP kolonunda $\mathrm{H}_{2} \mathrm{O}$ ve asetonitril ile oluşturulan hidrofobisite gradyenti sayesinde ayrılmaktadır (Şekil 7). Bunun için, başlangıçta kolondan $\% 100 \mathrm{H}_{2} \mathrm{O}(\% 0,1$ TFA ilaveli) geçişi ile hidrofilik proteinlerin ayırımı gerçekleştirilmekte, ardından asetonitril (\%0,08 TFA ilaveli) geçişi ile kolon içinde \%100 asetonitrile doğru bir gradyent akışı sağlanmaktadır. Böylece kolon içinde polardan apolara doğru bir ortam sağlanmakta ve hidrofobisitesi en düşük olan proteinlerden başlanarak gradyent boyunca hidrofobisitesi artan proteinlerin ayırımı gerçekleştirilmektedir. Kolondan ayrılan proteinler zamana bağlı olarak $(0,75 \mathrm{~mL} / 0,5 \mathrm{dk}) 2$. boyut fraksiyon toplayıcıda 96 kuyulu mikroplakalara fraksiyonlanmaktadır. Son olarak da \%100 asetonitril geçişiyle hidrofobisitesi en yüksek olan proteinlerin ayırımı yapılmakta ve 2. boyut ayırım tamamlanmaktadır.

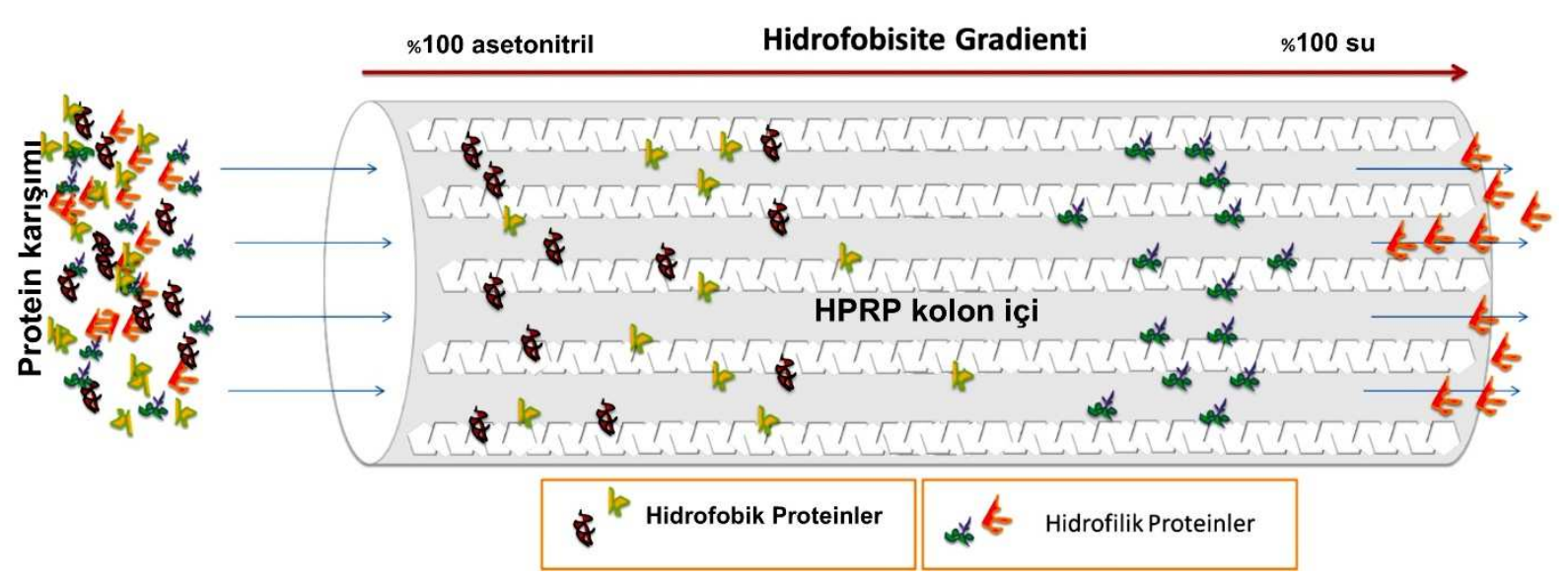

Şekil 7. İkinci boyut kolonda proteinlerin hidrofobisitelerine göre ayırımı

Bu modülde bulunan bir dedektör, proteinlerin peptid bağlarının 214nm dalga boyundaki absorbansını ölçerek daha hassas bir protein tespiti sağlamaktadır. Böylece elde edilen UV piklerinin her biri tek bir proteini temsil etmekte ve her fraksiyon için bu piklerden oluşan "II. boyut kromatogramı” oluşturulmaktadır. Bu süreç I. boyutta ayrılan ve II. boyuta transfer edilen her fraksiyon için tekrarlanmaktadır. Analizler süresince bilgisayar yazılımı üzerinden örneklerin birinci ve ikinci boyut kromatogramları kontrol edilebilmektedir.

\section{Jel Haritalarının Oluşturulması ve Karşılaştırma}

PF2D sisteminde iki boyutlu ayırım tamamlandıktan sonra elde edilen veriler sisteme özgü olarak geliştirilen ProteoVue yazılımı ile işlenerek sanal jel haritalarına dönüştürülür. Bunun için bir örneğin I. boyut ayırımında toplanan fraksiyonların $\mathrm{pH}$ aralık değerleri ve bu fraksiyonlardan her birinin II. boyut ayırımı sırasında elde edilen UV-2 kromatogramları birebir eşleştirilir. Bu şekilde bir örneğe ait, tüm fraksiyonların protein profili sanal jel haritalarında düzenlenerek iki boyutlu jel görüntüsü biçiminde elde edilmektedir (Şekil 8). 


\begin{tabular}{|c|c|c|}
\hline & $\begin{array}{l}\text { BŞEÜ Fen Bilimleri Dergisi } \\
7(1), 497-528,2020\end{array}$ & $\begin{array}{r}\text { BSEU Journal of Science } \\
\text { DOI: } 10.35193 / \text { bseufbd.667838 }\end{array}$ \\
\hline ERS & & 58-7575 (http://dergipark.gov.tr/bseufbd) \\
\hline
\end{tabular}

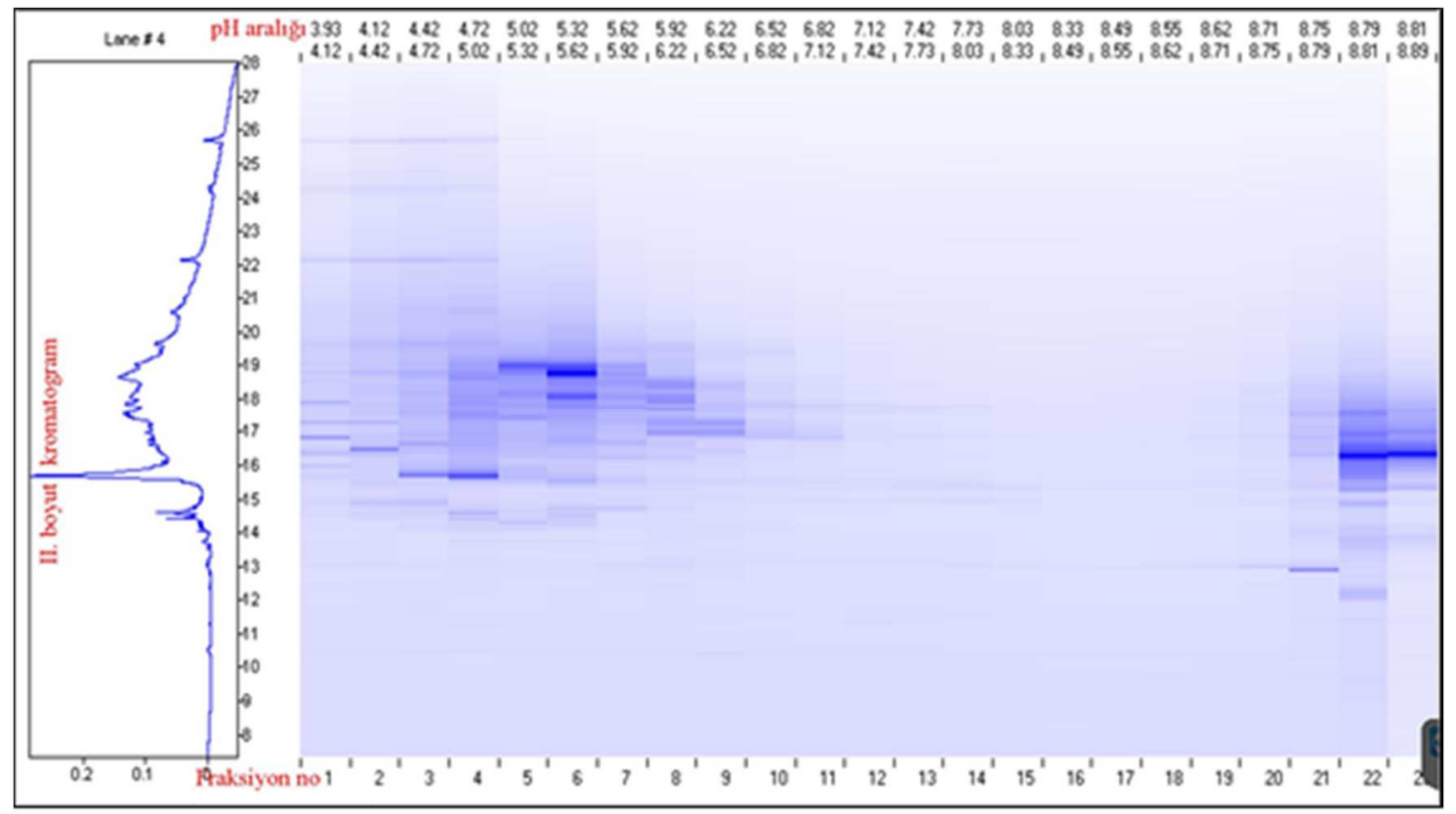

Şekil 8. 2D-LC sistemi ile ayrımı yapılmış proteinlerin 2 boyutlu sanal jel haritası

Kontrol ve uygulama yapılmış (test) örneklerin protein profillerinin karşılaştırılmasında ise yine PF2D sistemine özgün olarak geliştirilmiş olan yazılım (DeltaVue) programı kullanılmaktadır. Bunun için karşılaştırılmak istenen 2 örneğe ait sanal jel haritaları eş zamanlı olarak DeltaVue programında kontrol örnek sağda, test örneği solda (veya tersi) olacak şekilde açllır. Her örneğe ait haritada hem kromatogram hem de sanal jel görüntüsü birlikte izlenebilmektedir. Ortada ise iki örneğin karşılaştırılan fraksiyonlarında yer alan protein profilleri üst üste çakıştırılarak incelenebilmektedir. Daha detaylı karşılaştırma yapabilmek için her iki örneğin aynı pH aralığına sahip fraksiyonlarındaki protein bantları birebir karşılaştırılmalıdır ve II. boyut kromatogramlarında yer alan her bir protein piki birebir eşleştirilip numaralandırılır. Numaralanan her pik için pikin yükseklik ve genişliği baz alınarak alan hesabı yapılıp ekspresyon miktarı belirlenebilmektedir. Seçilerek numaralanan her pik için $\mathrm{pH}$ aralığı, miktarı, eşleştirildiği proteine göre miktarsal oranına dair detaylı bilgiler elde edilir. Sonuç olarak karşılaştırılan kontrol ve testlere ait tek tek tüm fraksiyonlar ve her fraksiyondaki tek tek tüm proteinler karşılaştırmalı olarak değerlendirilir. Böylelikle anlatım düzeyi farklı olan protein pikleri kolayca gözlenebilir (Şekil 9). Daha sonra da anlatım farkları oranı $\geq 2$ olan proteinler, biyolojik tekrarları ile istatiksel olarak değerlendirmeye tabii tutulur. İstatistik değerlendirmesi $\mathrm{p}<0.05$ olan proteinler ve eşleniği olan proteinlerin yer aldığı fraksiyonlar kütle spektrometresinde (MS) analiz edilmek üzere seçilir. Seçilen fraksiyonlar 1.5mL'lik

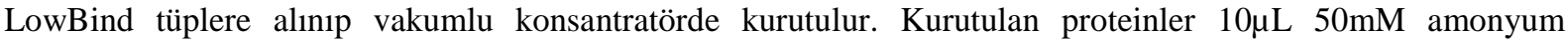
bikarbonat $\left(\mathrm{NH}_{4} \mathrm{HCO}_{3}\right)$ içerisinde çözündürülüp tripsinle kesim için hazır hale getirilir. Seçilen fraksiyonlarda bazen birden fazla protein bulunabilmektedir. Bu durumda bu fraksiyonda yer alan proteinler \%12'lik SDS-PAGE jeli ile III. boyut ayırıma tabii tutulur. Daha sonra istenen proteine ait bantlar jelden kesilerek tripsinizasyon uygulanır. 


\begin{tabular}{|c|c|c|}
\hline & $\begin{array}{l}\text { BŞEÜ Fen Bilimleri Dergisi } \\
7(1), 497-528,2020\end{array}$ & $\begin{array}{r}\text { BSEU Journal of Science } \\
\text { DOI: } 10.35193 / \text { bseufbd.667838 }\end{array}$ \\
\hline ERSI & & 58-7575 (http://dergipark.gov.tr/bseufbd) \\
\hline
\end{tabular}

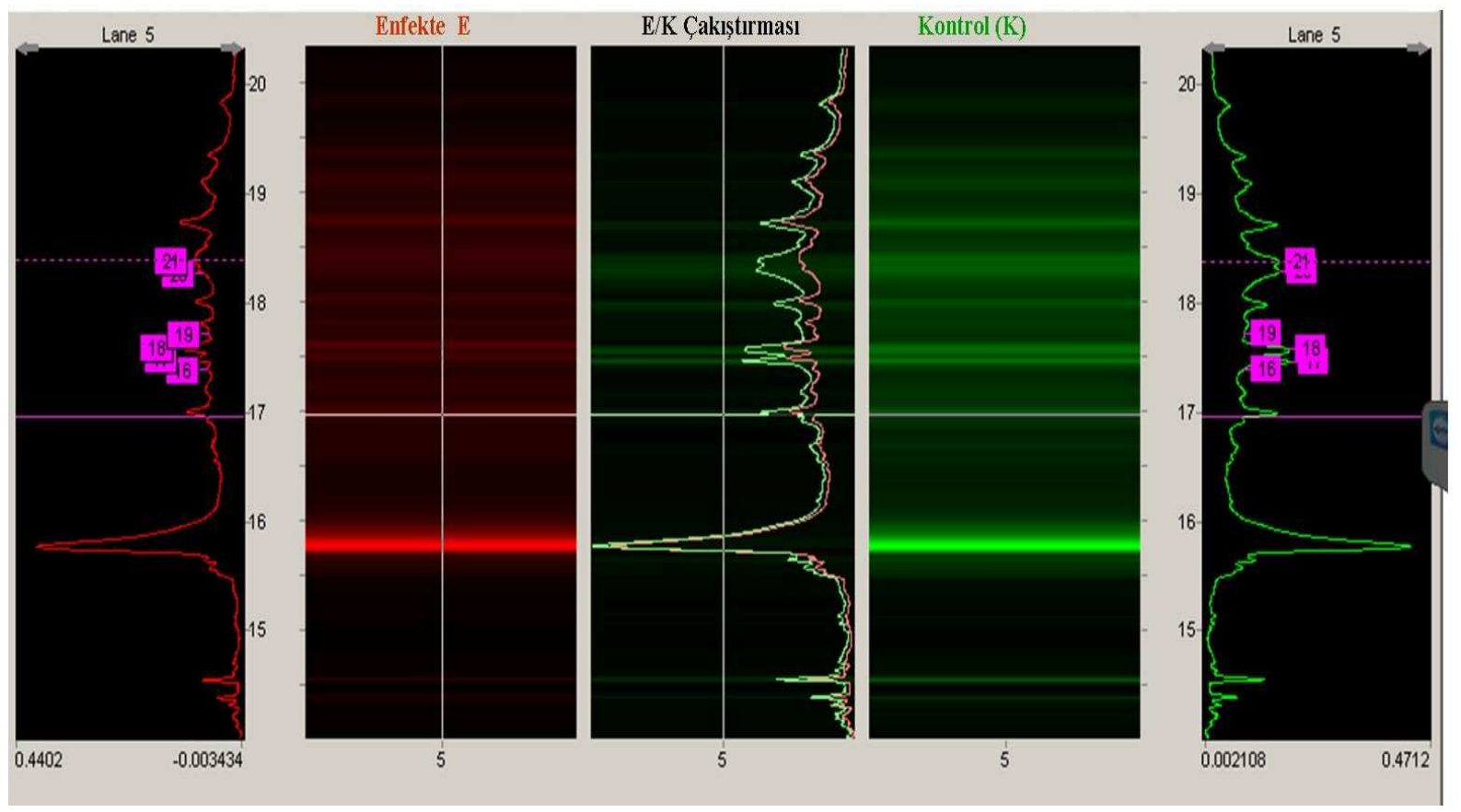

Şekil 9. PF2D sistemi ile ayrılan, kontrol ve enfekte bitkilere ait protein profillerinin karşılaştırılması (numaralı pikler ekspresyon farkı gözlenen proteinleri temsil etmektedir) [31].

\section{KÜTLE SPEKTROMETRESİ İLE PROTEIN TAYINİ}

Proteomik alanı ilk adımlarını jele dayalı yöntemlerle atmış olsa da tarihsel süreçte sıvı kromatografisine dayalı jelsiz yöntemler daha tercih edilir hale gelmiştir. Aslında jele dayalı ve jelsiz yöntemlerin her ikisi de tümevarımsal proteomik (bottom-up proteomics) kapsamında yer alır ki bu tanım bize protein tayininin, kısa protein parçaları olan peptitler üzerinden yapıldığını ifade etmektedir. Proteinden peptit elde etmek için de proteindeki amino asit zincirinin belirli noktalarından kesimler yapmak suretiyle onu küçük parçalara ayıran enzimler kullanılır. Tripsin, hem uygun kütle tayin aralığı bakımından hem de spesifik kesim yaptığı amino asitlerin pozitif yük avantajından ötürü kütle spektrometresi cihazlarında oldukça elverişli bir ortam sağladığı için sıklıkla tercih edilmektedir. Bu yönelim öyle bir boyut kazanmışıı ki günümüzde tripsin enzimi ile muamele adımı proteomik çalışmalarda standart bir uygulama olarak yer aldığı söylenebilir. İşte kütle spektrometresi ile protein tanımlaması, bu kısmi sekans analizine dayanır yani proteine ait bütün amino asit dizisinin bilinmesine gerek duyulmaz. Ancak belirli bir proteine ait peptitlerin tanımlaması ne kadar fazla olursa, o proteinin sekans kapsamı o kadar genişletilmiş olur ki bu da protein tanımlama güvenilirliğini arttırır.

Kütle spektrometresi ile aynı anda binlerce protein, karıșım halinde ve az miktarda üretilmişse bile analiz edilebilmektedir. Ancak cihaza verilmeden önce bu karışımlar yukarıda bahsi geçen jele dayalı veya jelsiz protein düzeyindeki ön ayırımlar ile daha az karmaşık fraksiyonlara indirgenebilir. Bu ön ayırımlara gerek duymayan ve proteinler tam karışım halindeyken doğruca tripsin parçalama işlemine tabi tutulan bir proteomik yaklaşımı da mevcuttur. Kaynağı olan proteinle bağı kopan ve daha da kompleks bir peptit havuzunun yaratıldığı bu yaklaşıma, genomikteki shotgun metoduna olan benzerlikten ötürü shotgun proteomik adı verilmiştir. Eğer geniş kapsamlı bir sonuç elde edilmek isteniyorsa, bu peptitler mümkün olan en iyi şekilde ayrılmış olarak kütle spektrometre cihazına gönderilmelidir. Bu peptit düzeyinde ön ayırma adımı, sıvı kromatografisinden fraksiyon eldesi, kesintisiz iki boyutlu sıvı kromatografisi (2D-LC), izoelektrik fokuslama, çok daha uzun ve etkili kolon tasarımı veya iyon mobilite özellikli kütle spektrometresi kullanımı gibi laboratuvarın imkanları ve tercihleri dahilinde çeşitli şekillerde uygulanabilir. Çoğunlukla, fazla sayıdaki fraksiyonlar, uzun süren 2D-HPLC elüsyonu, daha dar ve uzun kolonlar gerekli optimizasyonlar da yapılmışsa ayırımı güçlendirerek çok daha fazla veri eldesine olanak sağlar. 
Ne var ki kütle spektrometresi ile çok fazla veri elde edilmiş olması, elde edilen sonuçların kesin doğru olduğu anlamına gelmez çünkü kütle spektrometresi ile protein tayini birbirinden bağımsız en az üç farklı aşamada ilerler. Deneysel süreçlere dahil olan ilk iki aşamada proteinler hücreden ekstrakte edildikten sonra enzimle parçalanır ve parçalanma ürünlerinden; sinyal şiddetinin dikey eksende, kütle/yük oranının yatay eksende yer aldığı MS ve/veya MS/MS spektrumları elde edilir. Bu spektrumların eşleştirme yapan farklı programlar aracılığı ile veri tabanlarında da taratılması bilgisayar sistemlerinin dahil olduğu biyoinformatik alanının konusudur. Aslında kütle spektrometresi ile protein tayininde kesinlikten söz edilemez; zira veri tabanı taraması yapan her program sunduğu sonuçları belirli bir olasılık hesabı ile verir. Bu istatistiki hesaplardan güven aralığında olanlar doğru eşleşme yapmış varsayılır. Peptit parçalama spektrumlarını tarama motorları aracılığı ile uygun veri tabanında taratılması günümüz protein tanımlamasında standart bir uygulama haline gelmiş olsa da, ne yazık ki henüz bütün canlı türleri için veri tabanları oluşturulmuş değildir. Hali hazırda kullanılan veri tabanlarındaki protein dizilenmesine ait bilgiler ise, nükleotit dizilerinin bulunduğu kaynaklardan protein kodlamasında yer alanların in silico yani bilgisayar ortamında translasyon çevrimleriyle oluşturulur. Bu şekilde proteinler sadece fonksiyonları ile değil aynı zamanda onları meydana getiren gen bölgeleriyle de ilişkilendirilmiş olur. European Bioinformatics Institute (EMBL-EBI/Birleşik Krallık), Swiss Institute of Bioinformatics (SIB/İsviçre) ve Protein Information Resource (PIR-Amerika Birleşik Devletleri) arasındaki iş birliği ile kurulan UniProt [33] ve National Institute of Health'e (NIH/Amerika Birleşik Devletleri) bağlı NCBI [34] (National Center for Biotechnology Information), düzenli güncellenmeleri ve internet üzerinden halka açık kullanımları ile protein veri tabanları arasında en rağbet gören iki farklı kuruluştur.

Veri tabanı taramasının kullanılmadığı diğer bir metot olan yeniden (de novo) sekanslama da ise sadece MS/MS spektrumunda yer alan parçalanma ürünlerinin kütlelerine ait bilgilerden peptidin sekansı elde edilmeye çalışılır. Ancak bu uygulama hayli zorludur ve pratik sayılmaz dolayısıyla çok sık kullanılmaz zira MS/MS spektrumundaki parçalanmaya ait bilgiler çoğu zaman eksik olmakla birlikte gaz fazındaki çarpışmalarda meydana gelmiş çeşitli farklanmalar nedeniyle, kütle spektrumu beklenildiğinden daha karmaşık olabilmektedir. Parçalamayı gerçekleştiren çarpışmalı aktivasyon esnasında, yüksek enerji verilmesi, protonlanmış iyon halindeki peptidin omurgasında yer alan bağların çeşitli bölgelerden kırılmasına neden olmaktadır. Peptit parçalanmaları genelde pozitif modda çalışılır bu sebeple protonlanma herhangi bir amid bağındaki amino grubunda olabileceği gibi bazik amino asitlerin radikal gruplarındaki azot atomlarında da konumlanmış olabilmektedir. Peptit omurgasına ait bu bağlar üç çeşit olup alkil-karbonil bağı (CHR-CO), peptit amid bağı (CO-NH) ve amino-alkil bağının (NH-CHR) üçü de bu türden kopmalara açıktır. Şekilde 10'da çarpışmalı aktivasyon sonunda peptitlerin değişik bağlarının kırılması sonucunda oluşan ve en yoğun gözlenen iyon türleri gösterilmektedir.

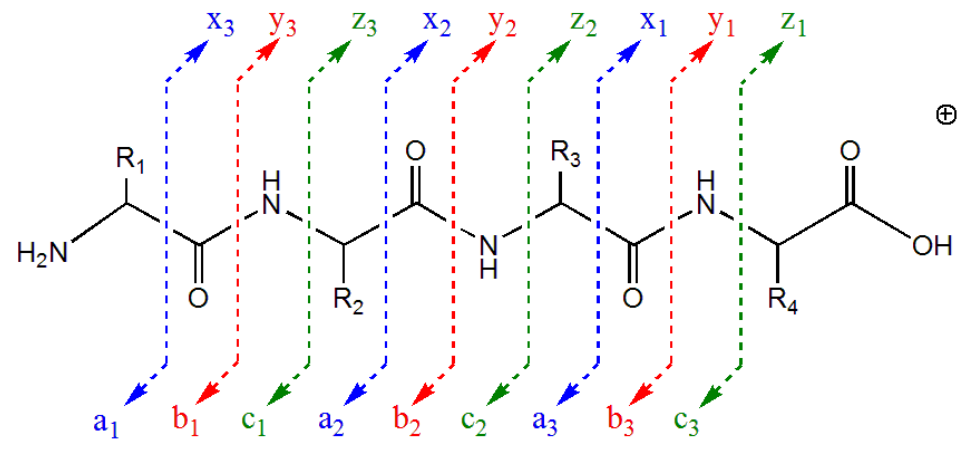

Şekil 10. Çarpışmalı aktivasyon sonunda peptitlerin değişik bağlarının kırılması sonucunda oluşan iyonlar

Bu kopmalar sonucunda yük, peptidin N- veya C- ucundan herhangi birinde yer alabilir. Dolayısıyla kopmanın gerçekleştiği bağa ve yükü taşıyan uca göre altı farklı tür iyon serisi oluşabilmektedir. Bu iyonlardan $\mathrm{N}$-ucuna ait iyonlar, $\mathrm{n}$ amino asit sayısını belirtmek üzere sırasıyla $a_{n}, b_{n}$ ve $c_{n}$ olarak; C ucuna ait iyonlar ise benzer şekilde $x_{n}, y_{n}$ ve $z_{n}$ olarak tanımlandırılır [35]. Şekilde gösterilmeyen fakat bu kopmaların dışında, yukarda belirtilmiş olan a, b veya y olarak iyon türlerinden su kopmasıyla oluşan iyon türleri literatürde $a^{\circ}, b^{\circ}, y^{\circ}$ ve amonyak kopmasıyla $a^{*}, b^{*}, y^{*}$ olarak kütle spektrumlarında gösterilirler. Ayrıca, yüksek enerjili parçalanma 


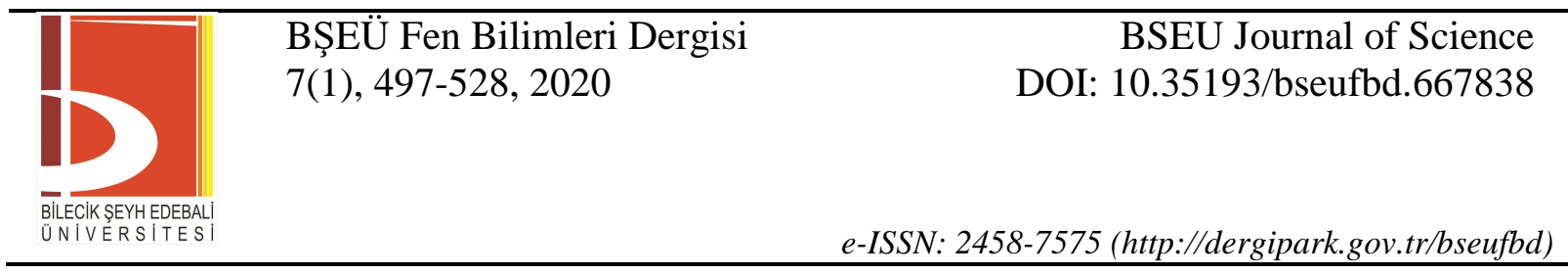

uygulamaları sonucunda, radikal gruplarındaki kopmalarla oluşan d, v, w iyonları (şekilde gösterilmemektedir) da gözlenmektedir. Bu farklı türden iyon serilerinin varlığı sekansı tayin etmeyi sağlayan bilgiyi taşısalar da bilgisayar kullanımını zorunlu kılan karmaşık spektrumların elde edilmesine neden olmaktadır. Bilindiği üzere, bu iyonlar spektrumlarda eşit sinyal şiddetiyle yansımaz, hatta hiç oluşmadığı da gözlenebilir. Peptidi oluşturan amino asit sekansları, peptit uzunluğu, asidik veya bazik amino asitlerin azlığı veya çokluğu, özellikle amino asidin yan zincirlerinde bulunan fonksiyonel gruplar, parçalanma sonrası oluşan iyonların oluşum mekanizmalarını, iyon türlerini ve iyon şiddetini önemli derecede etkilerler. Daha önce bahsedilen veri tabanı taramasının prensibi deneysel sonuçların bilgisayarda oluşturulan idealize spektrumlarla karşılaştırılması prensibine dayanır. Yani parçalanmış bir peptide ait olası tüm iyonları eşit şiddette içeren MS/MS spektrumları in-silico adı verilen yöntemle bilgisayarda oluşturulur ve deneysel elde edilen spektrumlar ile karşılaştırılır. Programı başlatmadan önce taramaya dair parametreler sisteme tanıtıldığında eşleşme imkânı arttırılarak tarama işlemi hızlandırılmış olunur. $\mathrm{Bu}$ parametreler arasında seçimi yapılanlar veri tabanı, organizma türü, proteinden peptit eldesinde kullanılan enzim, analizin yapıldığı kütle spektrometresi tipi ve peptidde bulunabilecek modifikasyonlardır. Bunun dışında iyon yükü, enzimin kesimi ıskaladığı (tripsin enzimi, $\mathrm{R}$ veya $\mathrm{K}$ aminoasitlerinin karboksil ucundan keser) bölge sayısı ve kütle toleransı, yani sinyalleri değerlendirirken tanınan esneklik değeri, belirtilmesi gerekilir. Parametrelerdeki değişiklikler tarama sonucunu etkilediği için mümkün olduğunca en uygun seçimler yapılarak işlem başlatılmalıdır. Yüksek kapasite ve işlem gücüne sahip bilgisayarların yaygınlaşıp daha geniş ortamlarda yer alması ile biyoinformatik alanında üretilen yazılımlar epey çeşitlik kazanmış olsa da piyasada uzun süredir yer alan programlar diğer çevreler tarafından sıklıkla kullanılması sebebiyle biriken bilgininde vermiş olduğu güvenle daha çok kabul görmektedir. Bunlar arasında The Scripps Research Institute tarafından geliştirilen SEQUEST [36] ve Matrix Science firmasının ürünü MASCOT [37] en eski ve en popüler programlar arasında yer alır. Şekil 11'de Mascot arama motoru ile gerçekleştirilecek olan veritabanı taraması sırasında girilmesi gereken parametrelere ait ekran görüntüsü verilmiştir.

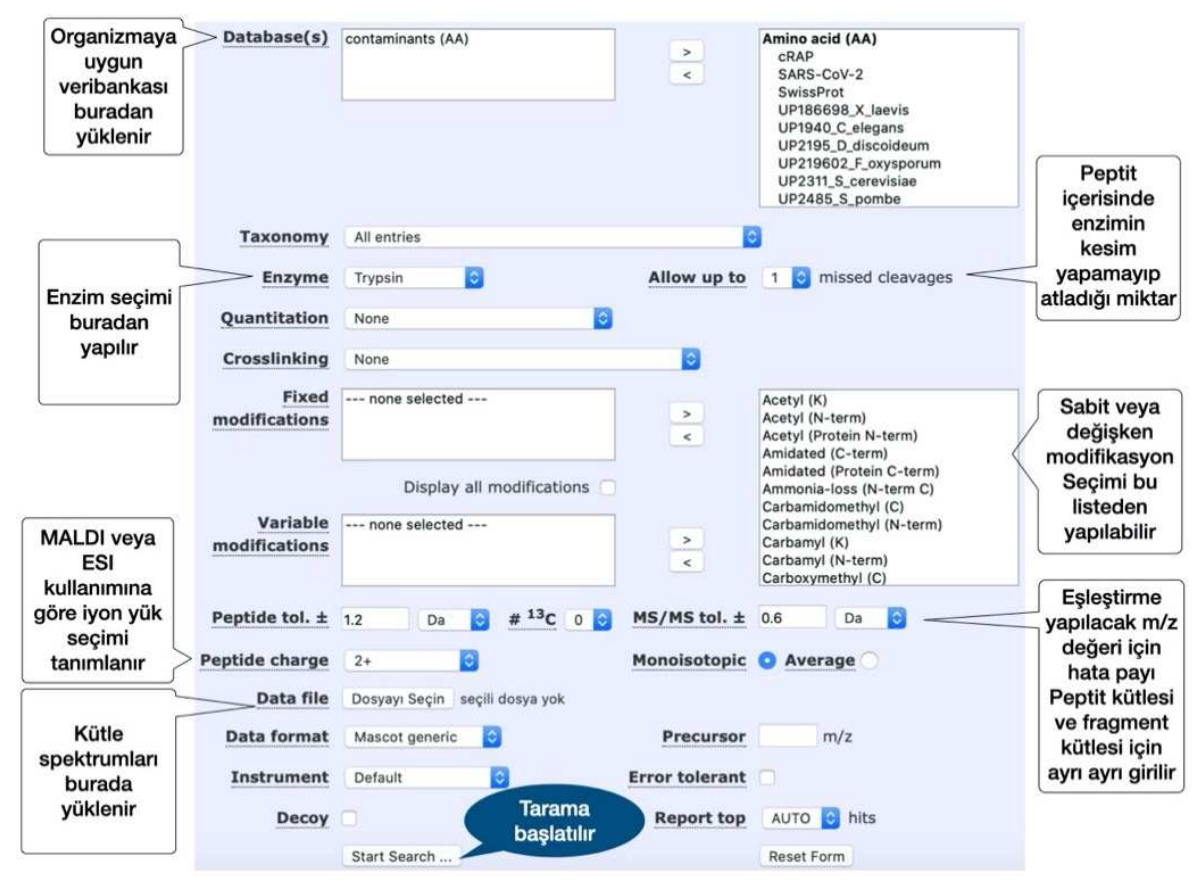

Şekil 11. Mascot (Matrix Science) arama motoru ile yapılan veritabanı taraması parametre seçim ara yüzü

Kütle spektrometre cihazlarını proteomik alanı için cazip kılan en önemli sebeplerden biri de otomatik kurulumla çok kısa sürede büyük veri (big data) eldesini mümkün kılmış olmasıdır. Elbette depolanan veri boyutu, analizlenecek örnek sayısına, sıvı kromatografisi programındaki elüsyon süresine ve kütle spektrometresindeki seçili veri toplama moduna (bütünsel/continuum veya kesikli/centroid) bağlı olduğu için bir bakıma kullanıcı 
insiyatifindedir. Ancak bunun haricinde, arttırılmış çözünürlük, tarama hızının yükseltilmesi ve iyon mobilite kaynaklı sürüklenme zamanı (drift time) gibi ilave özellik ve iyileştirmeler sayesinde günümüzdeki kütle spektrometre cihazları çok daha detaylı bilgi sunabilmektedir. Bu tür teknolojik gelişmelerin etkisi bilgisayar işletimlerine de yansıdığı için, bir zamanlar megabayt düzeyinde olan proteomik verileri bugün gigabaytlar seviyesine ulaşsa da makul hızda ve daha kapsayıcı olarak gerçekleştirilebilmektedir.

\section{A. MALDI Iyonlaştırmalı Kütle Spektrometresinde Peptit Analizi}

MALDI iyonlaştırma yönteminde, örnekler matris adı verilen ve genelde kütlesi küçük organik moleküller ile karıştırılıp metal bir plaka üzerinde kristalleştirmeye bırakılır. Kristalleşmiş olan örnek ve matris karışımı, tek dalga boyuna sahip pulse lazer kullanılarak yüzeyde foton bombalanmasına tabi tutulur. Bu esnada matris ve beraberinde analiz edilmek istenen örnek laser yardımı ile yüzeyden salınım ile ve eş zamanlı olarak iyonlaşma prosesine maruz bırakılır. Analizlenmek istenen örnekler bu matris molekülleri aracılığıly hem iyonlaşmış hem de dedektöre taşınmış olduğundan bu teknik MALDI (matrix-assisted laser desorption ionization) yani matriks yardımlı lazer yüzeyden salınımlı iyonlaştırma tamlamasının kısaltması olarak kabul görmüştür [38]. Protein ve peptit analizlerinde en çok kullanılan matriksler başta $\alpha$-siyano-4-hidroksisinaminik asit (CHCA) olmak üzere, 2,5-dihidroksibenzoik asit (DHB) ve 3,5-dimethoxy-4-hydroxycinnamic asittir (Sinapinik asit, SA). MALDI iyonlaştırmada, matriks ile örnek hazırlama dikkat edilmesi gerekilen önemli bir adımdır zira spektrumdaki iyonların sinyal kalitesini, matriks-iyon karışımının sıvı kısmı tamamen uzaklaşmış tam kristallerden oluşan doğru ön işlemler belirler.

MALDI iyonlaştırmalı sistemler lazer atımları süresince gerçekleştiğinden sıvı kromatografisinde olduğu gibi daimi veri işleme durumu yoktur onun yerine veriler kesitler halinde toplanır, bu bakımdan TOF (time of flight) adı verilen uçuş zamanlı kütle spektrometre analizörleri ile daha uyumlu çalışır.

MALDI iyonlaştırma yönteminde, örnekler matris adı verilen ve genelde kütlesi küçük organik moleküller ile karıştırılıp metal bir plaka üzerinde kristalleştirmeye bırakılır. Kristalleşmiş olan örnek ve matris karışımı, tek dalga boyuna sahip pulse lazer kullanılarak yüzeyde foton bombalanmasına tabi tutulur. Bu esnada matris ve beraberinde analiz edilmek istenen örnek laser yardımı ile yüzeyden salınım ile ve eş zamanlı olarak iyonlaşma prosesine maruz bırakılır. Analizlenmek istenen örnekler bu matris molekülleri aracılığıyla hem iyonlaşmış hem de dedektöre taşınmış olduğundan bu teknik MALDI (matrix-assisted laser desorption ionization) yani matriks yardımlı lazer yüzeyden salınımlı iyonlaştırma tamlamasının kısaltması olarak kabul görmüştür [38]. Protein ve peptit analizlerinde en çok kullanılan matriksler başta $\alpha$-siyano-4-hidroksisinaminik asit (CHCA) olmak üzere, 2,5-dihidroksibenzoik asit (DHB) ve 3,5-dimethoxy-4-hydroxycinnamic asittir (Sinapinik asit, SA). MALDI iyonlaştırmada, matriks ile örnek hazırlama dikkat edilmesi gerekilen önemli bir adımdır zira spektrumdaki iyonların sinyal kalitesini, matriks-iyon karışımının sıvı kısmı tamamen uzaklaşmış tam kristallerden oluşan doğru ön işlemler belirler.

MALDI iyonlaştırmalı sistemler lazer atımları süresince gerçekleştiğinden sıvı kromatografisinde olduğu gibi daimi veri işleme durumu yoktur onun yerine veriler kesitler halinde toplanır, bu bakımdan TOF (time of flight) adı verilen uçuş zamanlı kütle spektrometre analizörleri ile daha uyumlu çalışır. MALDI iyonlaştırma yöntemi, tek yüke sahip iyon oluşturması (kütle spektrumundaki $\mathrm{m} / \mathrm{z}$ değerleri için $\mathrm{z}=1$ olduğundan spektrum sadedir), geniş kütle aralığında ölçüm imkânı sunması, kontaminasyonlara karşı daha toleranslı olması ve öğreniminin kolay olması gibi özelliklerinden ötürü yaygın kullanım alanı bulmuştur.

Jele dayalı proteomik yaklaşımı, pratiklik kazandırması bakımından MALDI iyonlaştırma kütle spektrometreleri ile daha çok kullanılmaktadır çünkü proteinler izole halde oldukları için incelenen peptitlerin tek bir kaynaktan geldiği bilinir yani spektrumda $\mathrm{m} / \mathrm{z}$ değeri okunan bütün peptitler bir proteinden gelir. İlk proteomik çalışmalarında sadece bu peptitlerin kütlelerinden protein parmak izi (peptide mass fingerprint) adı verilen yöntemler ile tanımlama yapılabiliniyordu. Günümüzde bu yöntemden gerektiğinde faydalanılmasına rağmen güvenilirliği yetersiz kaldığı için o peptitlerin tercihen en az ikisinin cihaz içinde parçalanmasından elde edilen MS/MS spektrumlarına dayalı tanımlamalar daha güvenilir kabul edilmektedir.

Şekil 12'de tripsin ile kesim işlemi uygulanmış ve peptitlerine ayrılmış BSA proteinine ait peptit kütle spektrumu ve bu spektrumdan $\mathrm{m} / \mathrm{z}$ değeri 1567,70 olan peptit sinyalinin cihaz içinde spesifik seçimli izolasyonu 
sonrasında, enerji uygulanarak parçalanmasıyla elde edilen MS/MS kütle spektrumu verilmektedir. MS/MS spektrumunun düşük kütleleri içeren $\mathrm{m} / \mathrm{z}$ 40-200 aralığ sağlayan immonyum iyon sinyallerini barındırır. Örneğin m/z 60 serin, m/z 86 lösin veya izolösin, m/z 120 fenilalanin ve m/z 136 tirozin amino asitleri kaynaklı immonyum iyonları olabilir. İmmonyum iyon oluşumu, MALDI-TOF/TOF gibi yüksek enerjiyle çarpışmalı aktivasyona dayalı (high energy-CID) fragmentasyon tekniğinin kullanıldığı sistemlerde daha sık gözlemlenir. Daha büyük kütleli fragmentasyon iyonlarını barındıran $200-1600 \mathrm{~m} / \mathrm{z}$ aralığındaki diğer sinyaller, amino asitlerin hangi sırada olduklarına dair çıkarsama yapmaya yarayan birbirine tamamlayıcı b ve y iyonlarından yeterince içeriyorsa peptit dizilimi veya peptit sekanslaması biyoinformatik araçlarla yüksek skorlu olarak yapılabilir. Bu sinyallerden yeterince bulunmuyorsa program spektrumda yer alan yanıltıcı sinyalleri kullanarak yine de bir eşleştirmede bulunur ancak bu eşleştirmedeki düşük skor değeri yanlış peptit tanımlaması ihtimalini arttırır. $\mathrm{Bu}$ yüzden biyoinformatik araçlar istatiksel hesaplamalardan yararlanarak rastgelelik ihtimalini en aza indiren bir sınır skor değeri belirleyerek bu değeri aşan eşleştirmeleri doğru tanımlama olarak kabul eder.Jele dayalı proteomik yaklaşımı, pratiklik kazandırması bakımından MALDI iyonlaştırma kütle spektrometreleri ile daha çok kullanılmaktadır çünkü proteinler izole halde oldukları için incelenen peptitlerin tek bir kaynaktan geldiği bilinir yani spektrumda $\mathrm{m} / \mathrm{z}$ değeri okunan bütün peptitler bir proteinden gelir. İlk proteomik çalışmalarında sadece bu peptitlerin kütlelerinden protein parmak izi (peptide mass fingerprint) adı verilen yöntemler ile tanımlama yapılabiliniyordu. Günümüzde bu yöntemden gerektiğinde faydalanılmasına rağmen güvenilirliği yetersiz kaldığı için o peptitlerin tercihen en az ikisinin cihaz içinde parçalanmasından elde edilen MS/MS spektrumlarına dayalı tanımlamalar daha güvenilir kabul edilmektedir.

Şekil 12'de tripsin ile kesim işlemi uygulanmış ve peptitlerine ayrılmış BSA proteinine ait peptit kütle spektrumu ve bu spektrumdan $\mathrm{m} / \mathrm{z}$ değeri 1567,70 olan peptit sinyalinin cihaz içinde spesifik seçimli izolasyonu sonrasında, enerji uygulanarak parçalanmasıyla elde edilen MS/MS kütle spektrumu verilmektedir. MS/MS spektrumunun düşük kütleleri içeren $\mathrm{m} / \mathrm{z}$ 40-200 aralığı o peptit sekansında bulunan amino asitlerin tanısını sağlayan immonyum iyon sinyallerini barındırır. Örneğin m/z 60 serin, m/z 86 lösin veya izolösin, m/z 120 fenilalanin ve m/z 136 tirozin amino asitleri kaynaklı immonyum iyonları olabilir. İmmonyum iyon oluşumu, MALDI-TOF/TOF gibi yüksek enerjiyle çarpışmalı aktivasyona dayalı (high energy-CID) fragmentasyon tekniğinin kullanıldığı sistemlerde daha sık gözlemlenir. Daha büyük kütleli fragmentasyon iyonlarını barındıran $200-1600 \mathrm{~m} / \mathrm{z}$ aralığındaki diğer sinyaller, amino asitlerin hangi sırada olduklarına dair çıkarsama yapmaya yarayan birbirine tamamlayıcı b ve y iyonlarından yeterince içeriyorsa peptit dizilimi veya peptit sekanslaması biyoinformatik araçlarla yüksek skorlu olarak yapılabilir. Bu sinyallerden yeterince bulunmuyorsa program spektrumda yer alan yanıltıcı sinyalleri kullanarak yine de bir eşleştirmede bulunur ancak bu eşleştirmedeki düşük skor değeri yanlış peptit tanımlaması ihtimalini arttırır. Bu yüzden biyoinformatik araçlar istatiksel hesaplamalardan yararlanarak rastgelelik ihtimalini en aza indiren bir sınır skor değeri belirleyerek bu değeri aşan eşleştirmeleri doğru tanımlama olarak kabul eder. 


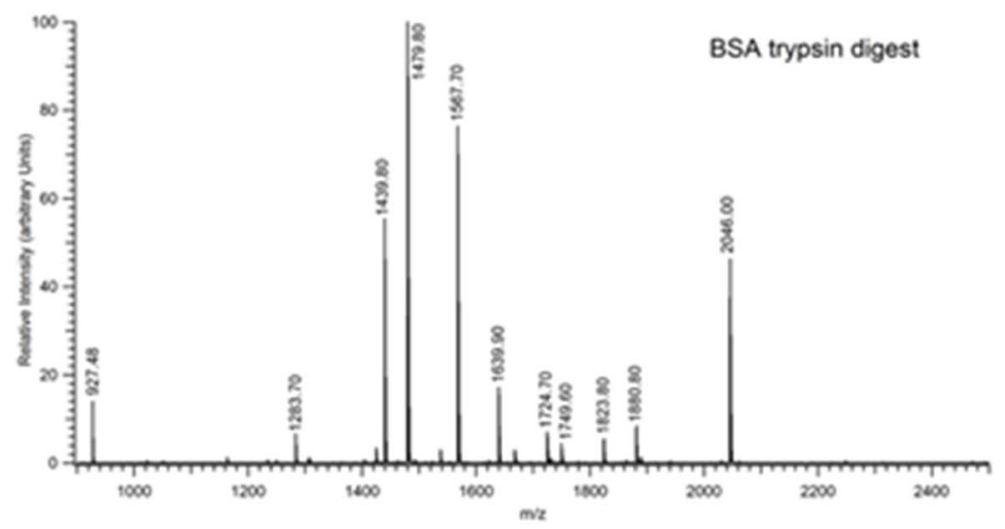

CID MS/MS spectrum of m/z 1567.70

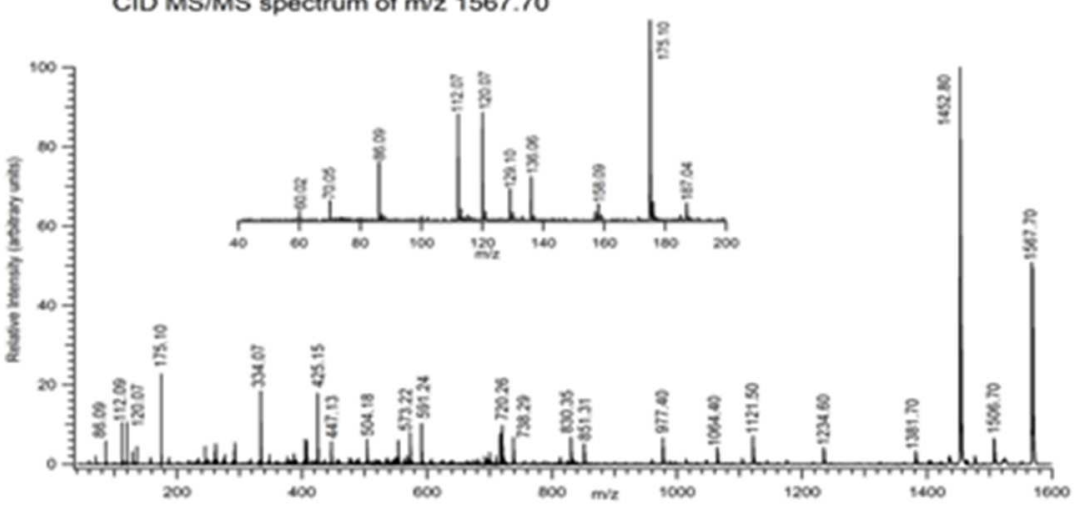

Şekil 12. Tripsin ile kesim işlemi uygulanmış BSA proteini MS spektrumu (üstte) ve bu spektrumda yer alan bir peptite ait MS/MS spektrumu (altta)

\section{B. LC-MS/MS ile Peptit Analizi}

Başta proteomik alanı olmak üzere diğer pek çok alandaki biyolojik örneğin kütle spektrometresi ile hızlı ve yüksek kapasiteli ölçümünü mümkün kılan LC-MS ve MS/MS sistemleri, analitik kimyada standart bir ayırma metodu olan sıvı kromatografisinin ışığı absorblayan bir UV dedektör yerine iyon dedektörü görevi gören bir kütle spektrometresi cihazı ile birleşiminden oluşmaktadır. Ayrılmış halde kolondan gelen moleküller, sıvı ortamda olduğu için iyonlaştırmaları elektrospray (ESI) adı verilen diğer yumuşak iyonlaştırma tekniği ile sağlanır. ESI sayesinde iğne gibi dar çaplı kapiler bir borudan geçen LC mobil fazına yüksek voltaj uygulanarak aeresol yapıdaki yüklü ve ufak damlacıklar elde edilir [39]. Bu damlacıklardaki sıvı sıcaklık artırımı ve gazla üflemesi gibi yardımcı müdahaleler ile uzaklaştırılarak yüklü tanecikler sistemin içine doğru çekilir. MALDI iyonlaştırmadan farklı olarak ESI de genelde çoklu yüke sahip iyonlar üretilmektedir.

Şekil 13'de Ubikütin proteinin elektrospray metodu ile alınmış ve değişik yük dağılımını gösteren kütle sinyali gösterilmektedir. Genelde biyopolimerlerin elektrospray ile elde edilen kütle sinyali burada olduğu gibi iyon şiddetleri farklı, +10 'dan fazla yük taşıyan birden çok $\mathrm{m} / \mathrm{z}$ sinyalini içerecek şekilde görülür. Bu çoklu protonlanmış kütle sinyalleri izole edilebilir parçalanmaya tabi tutulup bir proteine ait MS/MS spektrumu elde edilebilir. Tümden gelimsel (Top down) proteomik adını alan bu yöntemde bütün bir protein tanımlanabilmektedir ancak bu yöntem zorluğu ve özel gerekleri nedeniyle yaygın kullanımda değildir. Daha küçük yapıdaki peptitler hem çeşitli sıvı ortamlarında kolayca çözünmekte hem de kütle spektrometresinde detaylı olarak rahatça analizlenebilmektedir. Proteinlerse peptitlere kıyasla, sıvıda çözünmüş̧ halde izolasyonu oldukça güç ve fragmentasyon sonrası hayli kompleks MS/MS spektrumları veren çalışılması nispeten zor biyolojik materyallerdir. 


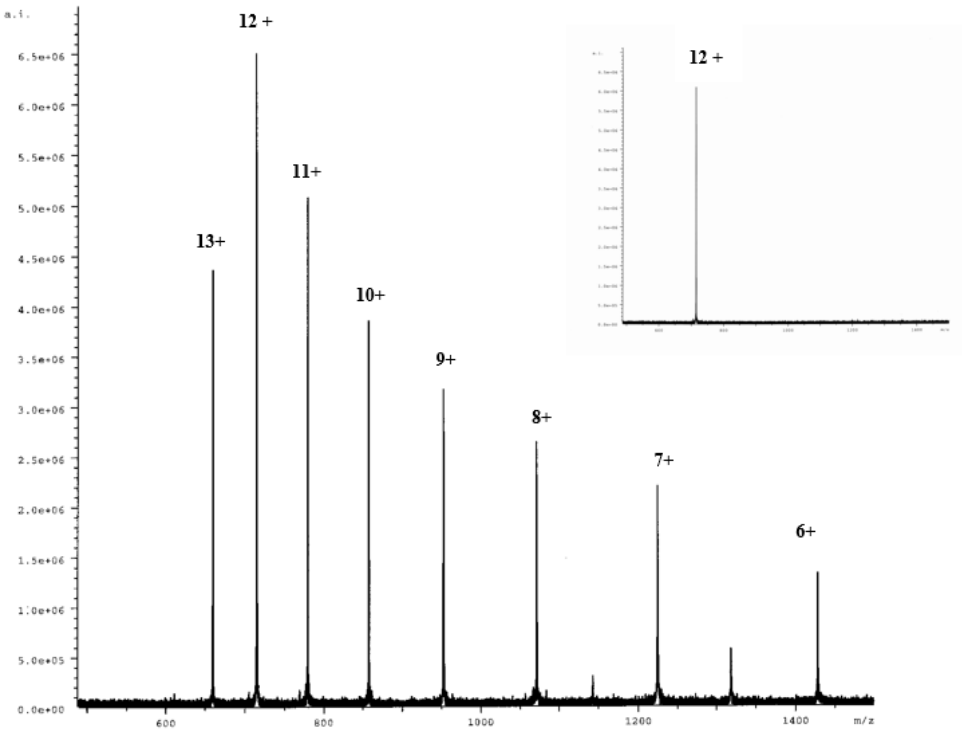

Şekil 13. Ubikütin proteinin ESI kütle spektrumu ve 12+ yüklü iyon sinyalinin izole edilmesi (küçük spektrum)

LC-MS/MS yönteminin proteomik alanında en etkin kullanımı, bilgi temelli data toplama (Datadependent acquisition, DDA) ismi verilen kesintisiz veri kaydının komut edilebilmesi sayesinde yani yazılımsal bir başarı ile mümkün olmuştur. Denetimsiz (unsupervised) tabir edilen bu otomatik kullanımda önceden belirlenmiş parametreler doğrultusunda cihaz peptitlerin MS spektrumunu ve seçili peptitlerin MS/MS spektrumunu saniyenin de altında hızlarla durmaksızın arka arkaya toplar. Böylece bir peptit için alıkonma zamanı, $\mathrm{m} / \mathrm{z}$ değeri ve onun parçalanma ürünleri hakkındaki eş zamanlı bilgiye sahip olunabilir. DDA modunun bilgi temelli olma hali hedef moleküllerin analiz şansını arttırmak için kullanıcı tarafından sisteme girilen parametrelere dayanır. Örneğin miktarı çok çok az olan sinyallerin zaten sonuç vermeyecek olan parçalanmalarını önlemek için iyon şiddeti olarak belir bir eşik değeri tanımlanır. Buna ek olarak, MS spektrumu alındıktan sonra kaç peptide parçalanma olacağı belirlenir ve aynı örneği defalarca analizlememek adına parçalanması yapılmış MS/MS spektrumu alınmış bir $\mathrm{m} / \mathrm{z}$ değeri için belirli bir süreliğine dişlama uygulaması (exclusion time) yapılır. Her ne kadar bu şekilde yüksek çıktı elde edilse de aynı örnekten aynı koşullarda toplanan veriler birebir aynı olmadığı için yöntemin doğasındaki bu rastgelelik (stochastic) genelde analiz tekrarı ile giderilmeye çalışılır. Şekil 14'te DDA ile toplanmış bir veriye ait LC kromatogramı (üstte) ve o kromatogramın 9,98. dakikasına karşılık gelen MS spektrumuna yer verilmiştir. Spektrumun üzerinde \# işareti ile gösterilen sayı, spektrum numarasını verir yani bu analizde ilk on dakika içerisinde 2500'den fazla spektrum elde edilmiş ve 9,98. dakika 2566 inc1 spektrum olarak kayda geçmiştir. 

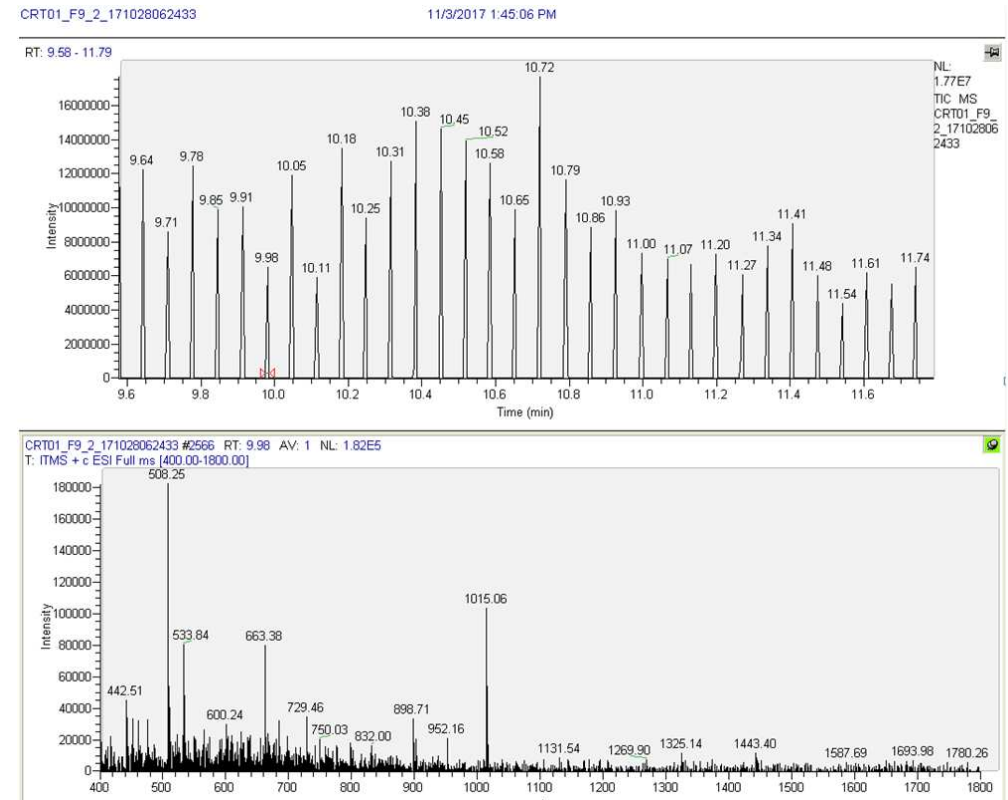

Şekil 14. Otomatik LC-MS/MS analizinde LC kromatogramı (üstte) ve MS spektrumu (altta) (Thermo LTQ-XL-MS,Xcalibur 2.0.7 den alınmıştır.)

Şekil 15'te, aynı analize ait üstte bir LC kromatogramı altta ise bu sefer $898,71 \mathrm{~m} / \mathrm{z}$ iyonunun parçalanma spektrumu yer almaktadır. Bu MS/MS spektrumundan alıkonma zamanının 9.99 ve spektrum numarasının 2569 olduğu görülüyor yani MS spektrumunun hemen arkasından parçalanma gerçekleşmiş. Tipik LC-MS/MS analizlerinin 1-2 saat arasında sürdüğü düşünülecek olursa, elimizde on binler hatta yüzbinlerce spektrum içerebilen ve bilgisayar yardımı olmadan değerlendirilmesi mümkün olmayan çıktı yığınları birikecek demektir. İşte bu noktada da kaçınılmaz bir şekilde, hesaplama yapan bilgisayarlar ve çeşitli biyoinformatik araçları devreye girer.

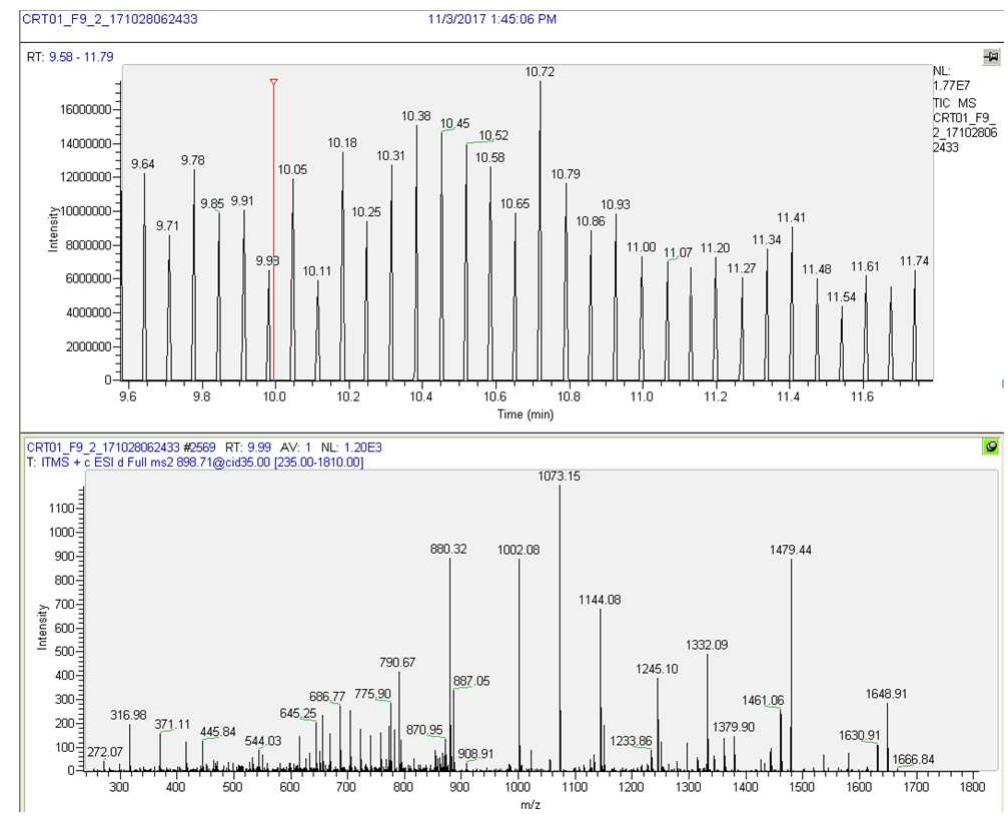


Şekil 15. Otomatik LC-MS/MS analizinde LC kromatogramı (üstte) ve MS/MS spektrumu (Thermo LTQ-XL-MS,Xcalibur 2.0.7 den alınmıştır.)

\section{Veritabanı Taraması ile Protein Tanımlanması}

Kütle spektrometresi ile protein tayini kısmında anlatılan, Mascot arama motoru ile veritabanı taraması ve protein tanımlanması işlemi ile elde edilen örnek bir sonuç Şekil 16'da verilmiştir. Bu örnekte bir proteinden tripsin enzimi ile kesim sonucu elde edilen peptitlerin MS/MS kütle spektrumları kullanılarak yapılan veri tabanı taramasında, peptitlerin sekansı ile ilgili proteinin tanımlaması yapılmış, yani kısmi sekans yardımıyla veritabanından bir protein tanımlanmıştır. MS/MS kütle spektrumu kullanılarak yapılan veri tabanı taramasında elde edilen bilgiler şu şekildedir: tanımlanan protein (ler)in adı, proteinin veritabanı kaydını gösteren gi numarası, olasılık temelli mowse skoru, histogram, protein molekül ağırlığ 1 ve eşleşen peptitler (kırmızı olarak belirtilen amino asit dizilimleri). Bu ekranda analiz sonucu tanımlanan protein seçildiği zaman ise proteine ait molekül ağırlığı, pI değeri, kısmi sekans örtüşmesinin proteinin hangi bölgesi ile örtüştüğü görülebilir (şekilde verilmemiştir). Mowse (Molecular Weight Search) skoru, Mascot tarafından olasılık temeline dayanan ve ilgili sonucun anlamlı ya da anlamsız olarak değerlendirilmesini sağlayan bir değerdir. Skora ait histogramdan hangi skor değerinin üzerindeki tanımlamaların anlamlı olacağı görülür. Bu analiz sonucunda skor değeri 38'in üzerinde tanımlanmış proteinlerin benzerlik ya da kapsamlı bir homoloji gösterdiği belirtilmiştir, yani anlamlı sonuçları ifade etmektedir. Araştırmacıların, bu ve benzeri protein tanımlama sonuçlarını değerlendirirken sonuçlarının güvenilirliğini sağlamaları için bahsedilen parametreleri dikkate almaları önerilmektedir.

\section{Л MAIRNCE Mascot Search Results}

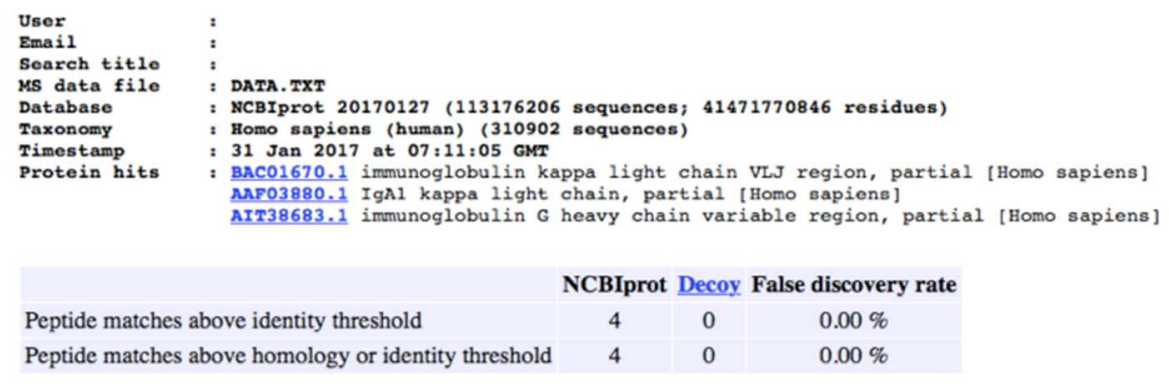

\section{Mascot Score Histogram}

Ions score is $-10 * \log (\mathrm{P})$, where $\mathrm{P}$ is the probability that the observed match is a random event. Individual ions scores $>38$ indicate identity or extensive homology $(p<0.05)$.

Protein scores are derived from ions scores as a non-probabilistic basis for ranking protein hits.

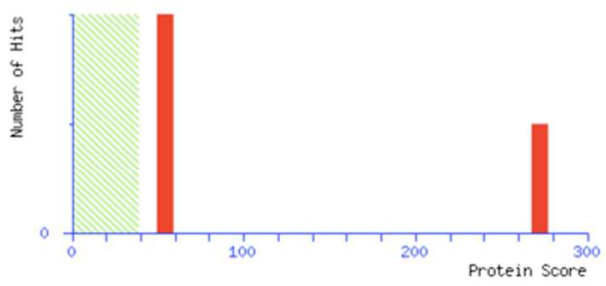

Peptide Summary Report

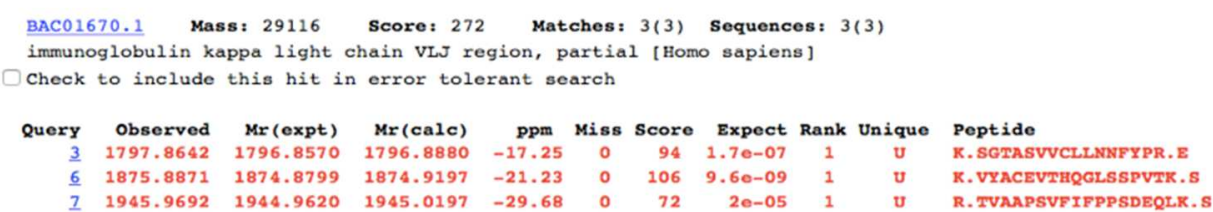

Şekil 16. MASCOT arama motoru kullanılarak yapılan veri tabanı taraması sonunda elde edilen örnek bir sonuç ekranı 


\section{IV.BITKİ PROTEOMIK ARAŞTIRMALARINDA GELECEK}

Birden fazla koşulun uygulandığı örneklerde veya zamanla Proteom profillerinin değişiminin anlaşılması gerektiğinde sıklıkla ek reaktif ya da pahalı kitler gerektirmemesi nedeni ile etiketlemenin yapılmadığı kütle spektrometresi yolu ile tanımlama tercih ediliyor. İşaretleme yöntemleri yetkin ve bütçesi elveren laboratuvarlarca uygulanmaktadır tabii burada en belirleyici faktörler örnek miktarının az olduğu durumlarda ve/veya standart yöntemlerle tespit etmenin zor olduğu düşük bolluktaki proteinlerin tespitinin hedeflenmiş olmasıdır. Bu etiketleme metotları ICAT (isotope coded affinity tag), SILAC (stable isotope labeling by amino acid in cell culture), ITRAQ (Isobaric tags for relative and absolute quantitation) reaktifleri ile işaretlemedir. ICAT yönteminde iki durum karşılaştırılır, SILAC işaretleme de bitki hücre kültürleri ile çalışmalar için uygunken [40] ITRAQ Yönteminde aynı anda 4 veya 8 örnekle çalışmak mümkündür, ayrıca bu yöntemlerle kantitatif karşılaştırmalı proteom farklılıkları tespit edilebilir [41].

Proteomik çalışmalarında amaçlanan sadece ifade edilen proteinlerin kimliklerinin niteliği değil aynı zamanda bu proteinlerin ne zaman hangi modifikasyonlarla ve nerede ifade edildiğini bilmektir. Özellikle bazı modifikasyonlar hem çok kararsız hem de çok azdır. Bu modifikasyonları tanımlayabilmek ilgili stres koşulunun araştırma konusu olan hipotezdeki rolünün anlaşılması veya söz konusu olan olayların altında yatan moleküler mekanizmaların anlaşılmasını sağlar. Doğal olarak görece daha oturmuş örnek hazırlama protokollerine sahip olan hayvansal organizmalar ve hücre kültür örneklerinde daha erken başlamış olan translasyon sonrası modifikasyonların aydınlatılması ile ilgili çalışmalar bitki proteomik araştırmalarında daha geç girmiştir. Örneğin hücre sinyalizasyon mekanizmalarında en etkili modifikasyonlardan biri olan fosforilasyon modifikasyonu klasik jel tabanlı ya da jelsiz tekniklerle hiçbir işlem yapılmadan bulunabilen fosforile protein Sayısı yüzde birdir. Ancak çeşitli zenginleştirme ön işlemleri uygulandığında fosforillenmiş proteinlerin tanımlanması mümkün olmaktadır bu amaçla titanyum dioksit ile zenginleştirme, immobilize metal affinite kromatografi ile zenginleştirme, yöntemleri literatürde en fazla karşılaşılanlardır. Diğer taraftan bu ön zenginleştirme yöntemlerini kullanmadan kütle spektrometresi analizleri esnasında tek veya çoklu reaksiyon izleme yöntemi sentezlenmiş iç standartlar kullandığından kesinliği ve tekrarlanabilirliği diğer metodlara üstündür. Üçlü-quadripol kütle spektrometresi analizleri uygulanır. Diğer taraftan yöntem zaman açısından tasarruflu bir yöntem olmadı̆̆ı gibi gerekli örnek miktarı da yüksektir [42, 43].

Bitki proteomik araştırmalarında gelecekte daha derin araştırılması gereken alanlardan biri de hücre altı proteomik çalışmalarıdır ki bunların sayıları aslında tüm ökaryotik organizmalar için sınırlıdır. Bir taraftan bu yapıların membranlı yapılar oluşu ve diğer taraftan yoğun emek gerektirmeleri bu organellerle ilgili çalışmaları sınırlayan faktörlerdir. Bitkiler de en fazla çalışılan hücre altı organeller mitokondri [44, 45] ve kloroplastlardır [46], çünkü bu organeller bitkinin enerji merkezleri olduğu gibi çeşitli biyotik/abiyotik streslere cevapta da etkin organellerdir. Organel temelli proteomik çalışmaları tanımlanan proteom kapsamını çok genişletecektir zira total protein ekstraksiyonları üzerinden gerçekleştirilen proteom çalışmaları ile tanımlanabilen proteinlerin önemli kısmı sitozolik proteinlerdir.

Omik yaklaşımlarını bir bütün olarak düşünerek yaklaşmak gerekliliği sistem biyolojisini doğurmuştur. Böylece genomik transkriptomik, proteomik, metalomik bulgularının çeşitli biyoinformatik araçlar vasıtası ile işlenmesine neden olmuştur [47]. Bu biyoinformatik araçlar moleküllerin hücre altı lokalizasyonlarının (WoLF PSORT: https://wolfpsort.hgc.jp) anlaşılması, salg1 proteinlerinin olup olmadıklarının belirlenmesi (Secretome P: http://www.cbs.dtu.dk/services/SecretomeP), protein-protein etkileşimlerinin belirlenmesi (String: https://stringdb.org) gibi informatik programlardır. Bu programların büyük kısmı web tabanlı programlar olup serbest erişime açıktır. Özellikle genom bilgisi ulaşılabilir organizmalar için tanımlanan proteinlerin fonksiyonlarının tahmin edilmesi için kullanılan programlar arasında yer alan ve sıklıkla tercih edilen Blast2Go gibi yazılımlar ücretli üyelikleri gerektirebilmektedir.

\section{SONSÖZ}

Proteomik çalışmaları ilk başladığı tarihlerden yakın zamana kadar, bitki yapısından ve içeriğinden kaynaklanan protein izolasyon ve ayırma basamaklarındaki problemler sebebi ile bitki örneklerinin kullanımına 
çok fazla olanak vermemiş olsa da gelişmiş teknolojik sistemler ve yeni metotlar sayesinde bitki örnekleri de günümüzde kolaylıkla analiz edilebilmektedir. Bu derlemede, yakın tarihe kadar bitkiler ile yapılmış proteomik çalışmalarından örnekler verilmiş, bitki örneklerinin proteomik analizlerine yönelik ihtiyacı olan tüm araştırmacılar için el kitabı sağlayacak seviyede detaylı ve püf noktaları sunan örnek hazırlama ve ayrıştırma yöntemleri protokolleri paylaşılmıştır. Her ne kadar örnek hazırlığı ve protein ayrıştırılması için kullanılan yöntemler bu derlemede verilenler ile sınırlı olmasa da birçok araştırmacı tarafından sıklıkla kullanılan yöntemlerden örneklendirmeler yapılmıştır. Bunun yanısıra, proteomik çalışmalarının temel yapıtaşlarını oluşturan izoelektrik fokuslama, jel elektroforezi, iki boyutlu jel elektroforezi, sıvı kromatografisi ve kütle spektrometresi tekniklerine yönelik teorik açıklamalara da yer verilmiştir. Yazarların, proteomik, bitki proteomiği, protein ayırma teknikleri ve kütle spektrometresi ile protein tanımlama alanlarındaki bilgileri ve tecrübeleri okurlar ile paylaşılarak yaralı bir kaynak oluşturulmaya çalışılmıştır. Unutulmaması gereken önemli noktalardan birisi 'SAMPLE HANDLING' diye bilinen, numunenin veya örneğin ön hazırlığı veya işlenmesi vs. basamaklarına çok dikkat edilmesidir. Analizi yapılacak örnekler ne kadar özenli ve titizlikle hazırlanırsa elde edilecek sonuçların güvenirliliği ve başarısı da ona göre kabul edile bilinir olacaktır. Ayrıca, karşılaştırmalı proteomik çalışmalarında, birbirleri ile karşılaştırılacak olan örneklerin tamamının, aynı gün ve aynı şartalarda analiz edilmesi elde edilecek sonuçların başarılı olması açısından önemlidir. PAGE (JEL) ile ayrıştırılan örnekler her ne kadar buz dolabında uzun süre saklana bilinir olması literatür tarafından kabul görmüş olsa da, deneyimlerimiz, 3-5 ay süre zarfında aynı gün ve aynı şartlarda elde edilmiş olan Jelde ayrıştılan proteinlerin analizlerinin değişebildiğini göstermiştir. 3-5 ay önce yapılan bir analizin, benzer jelden alınan ve 3-5 ay sonra yapılan aynı protein örneğinin analizinin farklılık gösterdiği tarafımızdan gözlemlenmiş bir sonuçtur.

Son olarak, yapılacak proteomik çalışmalarında, araştırmalarında, izole edilen, saflaştırılan örneklerin hepsinin analizlerinin mümkün olan en kısa sürede, aynı şartlarda ve aynı zaman diliminde yapılması, elde edilecek sonuçların tekrarlanabilirliği açısından önemlidir.

\section{Notlar}

1.Proteomik araştırmalarında örnek hazırlığından 2D-PAGE ile ayrılan proteinlerin kütle spektrometresi için hazırlanması dahil bütün adımlarında kullanılan kimyasal maddelerin yüksek kalitede olması ve çözelti ve tampon hazırlıklarında kullanılan suyunda direncinin en azından 18M $\Omega$ olması gerekmektedir. Ayrıca 2D-PAGE tekniğinin 1. aşaması olan IEF kısmında özellikle IPG striplerin kullanıldığı IEF işlemlerinde örnekteki tuz miktarının 10mM'ın altında olması gerekmektedir. Çünkü IEF işleminde kullanılan ister IPG strip isterse tube-cell yöntemi olsun tuz toleransı çok düşüktür.

2.Proteomik çalışmalarının gerçekleştirileceği laboratuvarlarda mutlaka bir IEF sistemi bir de 2. boyutun gerçekleştirileceği 2. boyut elektroforez sistemi bulunmalıdır. Biz laboratuvarımızda GE Healthcare' ait olan 1. boyut için IPGPhor III ve 2 . boyut için ise Ettan Dalt $6(25 \times 20 \mathrm{~cm})$ sistemini kullanmaktayı.

3.Diğer önemli ekipman ise soğutmalı yüksek devirli santrifüj.

4.Bitki materyali yüksek miktarda fenolik bileşikler içermesi nedeni ile bu bileşikler hem protein miktarının doğru tayinini engeller hem de elektroforez rezolüsyonunu düşürür. Bu nedenle bitki dokuları ile çalışılırken muhakkak PVPP kullanılmalı ve bu reaktif sıvı azot ile toz haline getirme aşamasında katı olarak eklenmelidir.

5.TCA/Aseton çöktürme yöntemi sırasında pelletin yıkanması işlemlerinde pellet hareketli olabileceğinden süpernatantın uzaklaştırılması dikkatli yapılmalıdır.

6.Soğuk aseton-DTT çözeltisi ile yıkama işlemi -bitki dokuları ile özellikle pigmentasyonun yüksek olduğu dokularda yaprak gibi- en az 6 kere tekrarlanmalı, eğer hala süpernatant renk içeriyorsa yıkama işlemi 8 e çıkarılmalıdır.

7.Protein örneklerinin hazırlanmasında SDS gibi deterjanların konsantrasyonlarının ayarlanması kritiktir çünkü bu deterjanlar Kütle spektrometresi analizleri için örnek hazırlanırken tripsin etkinliğini azaltmaktadır. 

değiştirir.

8.Fenol-SDS yöntemi için direkt fenol çözeltisi kullanılacaksa o taktirde toplanacak olan fenol fazı yer

\section{KAYNAKLAR}

[1] Wilkins, M.R., Pasquali, C., Appel, R.D., Ou, K., et al., (1996). From proteins to proteomes: Large scale protein identification by two-dimensional electrophoresis and amino acid analysis. Bio/Technology , 14, 6165 .

[2] Konishi, T., (2001). Genetic diversity in Hordeum agriocrithon E. Åberg, six-rowed barley with brittle rachis, from Tibet. Genet. Resour. Crop Evol. 110, 145-150.

[3] Imin, N., Kerim, T., Weinman, J.J., Rolfe, B.G., (2001). Characterisation of rice anther proteins expressed at the young microspore stage. Proteomics, 1, 1149-1161.

[4] Mandelc, S., Javornik, B., Majeran, W., Cai, Y., et al., (2004). A proteomics approach towards understanding blast fungus infection of rice grown under different levels of nitrogen fertilization. Proteomics, 14, $311 \mathrm{LP}-$ 325 .

[5] Schubert, M., Petersson, U.A., Haas, B.J., Funk, C., et al., (2002). Proteome map of the chloroplast lumen of Arabidopsis thaliana. J. Biol. Chem, 277, 8354-8365.

[6] Shen, S., Matsubae, M., Takao, T., Tanaka, N., Komatsu, S. (2002). A proteomic analysis of leaf sheaths from rice. Journal of biochemistry, 132(4), 613-620.

[7] Bindschedler, L. V., Burgis, T.A., Mills, D.J.S., Ho, J.T.C., et al., (2009). In planta proteomics and proteogenomics of the biotrophic Barley fungal pathogen Blumeria graminis f. sp. hordei. Mol. Cell. Proteomics, 8, 2368-2381.

[8] Rampitsch, C., Günel, A., Beimcik, E., Mauthe, W. (2015). Proteome of monoclonal antibody-purified haustoria from Puccinia triticina Race-1. Proteomics, 15, 1307-1315.

[9] Rampitsch, C., Bykova, N. V., McCallum, B., Beimcik, E., Ens, W. (2006). Analysis of the wheat and Puccinia triticina (leaf rust) proteomes during a susceptible host-pathogen interaction. Proteomics, 6, 18971907.

[10] Kim, S. T., Kim, S. G., Hwang, D. H., Kang, S. Y., Kim, H. J., Lee, B. H., Lee, J. J., Kang, K. Y. (2004). Proteomic analysis of pathogen-responsive proteins from rice leaves induced by rice blast fungus, Magnaporthe grisea. Proteomics, 4, 3569-3578.

[11] Gunel, A., Asbahi, A., Ozgazi, N., Akkaya, M.S., (2012). Identification of differentially expressed proteins in wheat after benzothiadiazole treatment. J. Plant Dis. Prot. 119.

[12] Jung, Y. H., Jeong, S. H., Kim, S. H., Singh, R., Lee, J. E., Cho, Y. S., Agrawal, G. K., Rakwal, R., Jwa, N. S. (2012). Secretome analysis of Magnaporthe oryzae using in vitro systems. Proteomics, 12, 878-900.

[13] Rampitsch, C., Day, J., Subramaniam, R., Walkowiak, S. (2013). Comparative secretome analysis of Fusarium graminearum and two of its non-pathogenic mutants upon deoxynivalenol induction in vitro. Proteomics, 13, 1913-1921.

[14] Hochholdinger, F., Guo, L., Schnable, P. S. (2004). Cytoplasmic regulation of the accumulation of nuclearencoded proteins in the mitochondrial proteome of maize. The Plant journal : for cell and molecular biology, 37, 199-208.

[15] Lonosky, P. M., Zhang, X., Honavar, V. G., Dobbs, D. L., Fu, A., Rodermel, S. R. (2004). A proteomic analysis of maize chloroplast biogenesis. Plant physiology, 134, 560-574. 
[16] Majeran, W., Cai, Y., Sun, Q., van Wijk, K. J. (2005). Functional differentiation of bundle sheath and mesophyll maize chloroplasts determined by comparative proteomics. The Plant cell, 17, 3111-3140.

[17] Zhu, J., Alvarez, S., Marsh, E. L., Lenoble, M. E., Cho, I. J., Sivaguru, M., Chen, S., Nguyen, H. T., Wu, Y., Schachtman, D. P., Sharp, R. E. (2007). Cell wall proteome in the maize primary root elongation zone. II. Region-specific changes in water soluble and lightly ionically bound proteins under water deficit. Plant physiology, 145, 1533-1548.

[18] Dunkley, T. P., Hester, S., Shadforth, I. P., Runions, J., Weimar, T., Hanton, S. L., Griffin, J. L., Bessant, C., Brandizzi, F., Hawes, C., Watson, R. B., Dupree, P., Lilley, K. S. (2006). Mapping the Arabidopsis organelle proteome. Proceedings of the National Academy of Sciences of the United States of America, 103, 65186523.

[19] Maltman, D. J., Gadd, S. M., Simon, W. J., Slabas, A. R. (2007). Differential proteomic analysis of the endoplasmic reticulum from developing and germinating seeds of castor (Ricinus communis) identifies seed protein precursors as significant components of the endoplasmic reticulum. Proteomics, 7, 1513-1528.

[20] Fernando, U., Chatur, S., Joshi, M., Thomas Bonner, C., Fan, T., Hubbard, K., Chabot, D., Rowland, O., Wang, L., Subramaniam, R., Rampitsch, C. (2019). Redox signalling from NADPH oxidase targets metabolic enzymes and developmental proteins in Fusarium graminearum. Molecular plant pathology, 20, 92-106.

[21] Rampitsch, C., Huang, M., Djuric-Cignaovic, S., Wang, X., Fernando, U. (2019). Temporal Quantitative Changes in the Resistant and Susceptible Wheat Leaf Apoplastic Proteome During Infection by Wheat Leaf Rust (Puccinia triticina). Frontiers in plant science, 10, 1291.

[22] Fang, X., Chen, J., Dai, L., Ma, H., Zhang, H., Yang, J., Wang, F., Yan, C. (2015). Proteomic dissection of plant responses to various pathogens. Proteomics, 15, 1525-1543.

[23] Unlü, M., Morgan, M. E., Minden, J. S. (1997). Difference gel electrophoresis: a single gel method for detecting changes in protein extracts. Electrophoresis, 18, 2071-2077.

[24] Wittig, I., Braun, H. P., Schägger, H. (2006). Blue native PAGE. Nature protocols, 1, 418-428.

[25] Karger, B. L., Guttman, A. (2009). DNA sequencing by CE. Electrophoresis, 30 Suppl 1(Suppl 1), S196S202.

[26] Görg, A., Obermaier, C., Boguth, G., Harder, A., Scheibe, B., Wildgruber, R., \& Weiss, W. (2000). The current state of two-dimensional electrophoresis with immobilized pH gradients. Electrophoresis, 21, 10371053.

[27] Wang, W., Scali, M., Vignani, R., Spadafora, A., Sensi, E., Mazzuca, S., Cresti, M. (2003). Protein extraction for two-dimensional electrophoresis from olive leaf, a plant tissue containing high levels of interfering compounds. Electrophoresis, 24, 2369-2375.

[28] Neuhoff, V., Arold, N., Taube, D., Ehrhardt, W. (1988). Improved staining of proteins in polyacrylamide gels including isoelectric focusing gels with clear background at nanogram sensitivity using Coomassie Brilliant Blue G-250 and R-250. Electrophoresis, 9, 255-262.

[29] Zörb, C., Betsche, T., Langenkämper, G. (2009). Search for diagnostic proteins to prove authenticity of organic wheat grains (Triticum aestivum L.). Journal of agricultural and food chemistry, 57, 2932-2937.

[30] Finnie, C. 2006. Plant proteomics. Annual Plant Reviews. 28: ISBN:1-405 1-4429-7. Blackwell Yayınevi.

[31] Demirci, YE., Inan, C., Günel, A., Maytalman, D., Mert, Z., Baykal, AT.,Vural-Korkut,

[32] S., Arda, N. \& Hasançebi S. (2016). Proteome profiling of the compatible interaction between wheat and stripe rust. European Journal of Plant Pathology, 1-22. 
[33] Kim, ST., Cho, KS., Jang YS., Kang YK. (2001) Two dimensional electrophoretic analysis of rice proteins by polyethylene glycol fractionation for protein arrays. Electrophoresis. 22:2103-2109.

[34] UniProt: the universal protein knowledgebase. Nucleic Acids Res. 2017

[35] Ncbi Resource Coordinators, Database Resources of the National Center for Biotechnology Information. Nucleic Acids Res. 2017

[36] Novel fragmentation process of peptides by collision-induced decomposition in a tandem mass spectrometer: differentiation of leucine and isoleucine Anal. Chem. 1987Richard S. Johnson, Stephen A. Martin, Klaus. Biemann, John T. Stults, and J. Throck. Watson

[37] An approach to correlate tandem mass spectral data of peptides with amino acid sequences in a protein database. Jimmy K.EngAshley L.McCormackJohn R.YatesIII, J Am Soc Mass Spectrom 1994

[38] Perkins, D. N.; Pappin, D. J. C.; Creasy, D. M.; Cottrell, J. S., Probability-based protein identification by searching sequence databases using mass spectrometry data. Electrophoresis 1999, 20 (18), 3551-3567

[39] Karas, M.; Bachmann, D.; Bahr, U.; Hillenkamp, F., Matrix-assisted ultraviolet laser desorption of nonvolatile compounds. International Journal of Mass Spectrometry and Ion Processes 1987, 78, 53-68.

[40] Fenn, J.; Mann, M.; Meng, C.; Wong, S.; Whitehouse, C., Electrospray ionization for mass spectrometry of large biomolecules. Science 1989, 246 (4926), 64-71

[41] Matthes, A., Köhl K., Schulze, WX., SILAC and alternatives in studying cellular proteomes of plants. Methods Mol Biol. 2014;1188:65-83. doi:10.1007/978-1-4939-1142-4_6

[42] Liu, B., Shan, X., Wu, Y., Su, S., Li, S., Liu, H., Han, J., Yuan, Y. (2018). iTRAQ-Based Quantitative Proteomic Analysis of Embryogenic and Non-embryogenic Calli Derived from a Maize (Zea mays L.) Inbred Line Y423. International journal of molecular sciences, 19(12), 4004.

[43] Van Ness, L. K., Jayaraman, D., Maeda, J., Barrett-Wilt, G. A., Sussman, M. R., Ane, J. M. (2016). Mass spectrometric-based selected reaction monitoring of protein phosphorylation during symbiotic signaling in the model legume, Medicago truncatula. PloS one, 11(5).

[44] Arsova, B., Watt, M., Usadel, B. (2018). Monitoring of plant protein post-translational modifications using targeted proteomics. Frontiers in plant science, 9, 1168.

[45] Fuchs, P., Rugen, N., Carrie, C., Elsässer, M., Finkemeier, I., Giese, J., Schallenberg-Rüdinger, M. (2020). Single organelle function and organization as estimated from Arabidopsis mitochondrial proteomics. The Plant Journal, 101, 420-441.

[46] Niehaus, M., Straube, H., Künzler, P., Rugen, N., Hegermann, J., Giavalisco, P., Herde, M. (2020). Rapid affinity purification of tagged plant mitochondria (Mito-AP) for metabolome and proteome analyses. Plant Physiology, 182, 1194-1210.

[47] Wang, Y., Li, X., Liu, N., Wei, S., Wang, J., Qin, F., Suo, B. (2020). The iTRAQ-based chloroplast proteomic analysis of Triticum aestivum L. leaves subjected to drought stress and 5-aminolevulinic acid alleviation reveals several proteins involved in the protection of photosynthesis. BMC plant biology, 20, 1-17.

[48] Wang X. (2019). Protein and Proteome Atlas for Plants under Stresses: New Highlights and Ways for Integrated Omics in Post-Genomics Era. International journal of molecular sciences, 20, 5222. 